\title{
Late Palaeozoic lithostratigraphy of the Andean Precordillera revisited (San Juan Province, Argentina)
}

\author{
F. Colombo ${ }^{1 *}$, C.O. Limarino ${ }^{2}$, L.A. Spalletti ${ }^{3}$, P. Busquets ${ }^{1}$, R. Cardó ${ }^{4}$, I. Méndez-Bedia ${ }^{5}$, N. Heredia ${ }^{6}$ \\ ${ }^{I}$ Dept. Estratigrafia, Paleontologia y Geociencias Marinas. Facultad de Geología, Universidad de Barcelona, C/ \\ Marti-i-Franquès s/n. E-08028 Barcelona, Spain. \\ ${ }^{2}$ Dept. Geología. Facultad de Ciencias Exactas y Naturales. Universidad de Buenos Aires. Ciudad Universitaria. \\ Pabellón II, 1428 Buenos Aires, Argentina. \\ ${ }^{3}$ Centro de Investigaciones Geológicas CIG-CONICET. Universidad Nacional de La Plata. Calle 1, $n^{\circ}$ 644, 1900 La Plata, Argentina. \\ ${ }^{4}$ Universidad Nacional de San Juan. Servicio Geológico Minero Argentino (SEGEMAR), Sargento Cabral, 685 Oeste. \\ 5400 San Juan, Argentina. \\ ${ }^{5}$ Dept. de Geología. Facultad de Geología. Universidad de Oviedo. C/Jesús Arias de Velasco s/n. E-33005 Oviedo, Spain. \\ ${ }^{6}$ Instituto Geológico y Minero de España (IGME), Matemático Pedrayes, 25, E-33005 Oviedo, Spain.
}

e-mail addresses: colombo@ub.edu (F.C., Correspondingauthor); pere.busquets@ub.edu (P.B.);limar@gl.fcen.uba.ar(C.O.L.);spalle@cig.museo.unlp.edu.ar (L.A.S); rcardo@segemarsj.com.ar (R.C.); imbedia@geol.uniovi.es (I.M.-B.); n.heredia@igme.es (N.H.)

Received: 17 March 2014 / Accepted: 25 May 2014 / Available online: 25 June 2014

\begin{abstract}
New data on some neopalaeozoic lithostratigraphic units of the central sector of the Argentinean Precordillera are presented. The western Precordillera displays occasional outcrops of siliciclastic rocks of the Late Palaeozoic. These rocks are separated by two main unconformities related to the development of the Chanic (Upper Devonian-early Carboniferous) and Gondwanan (late Carboniferous-early Permian) orogens. A major unconformity marks the beginning of the Andean cycle in middle Permian times. The Del Ratón Formation (800 m) in the studied area is made up of conglomerates and can be divided into two units. The basal part (Lower Member) was deposited in a fjord environment. The Upper Member was generated by an alluvial system that was mainly dominated by upper flow-regime plane beds, whereas its uppermost part accumulated in a fan delta setting. The clast provenance and the main palaeocurrents suggest the existence of a significant topographic high to the W and NW of the present outcrops. The El Planchón Formation (1400 m) is mainly composed of shales and sandstones as a result of sedimentation in a deep-sea fan environment. These lutite-dominated materials graded laterally northwards into conglomerates in a glacial setting. The Del Ratón and El Planchón formations of the Lower Carboniferous correspond to the synorogenic Chanic sedimentation (Chanic foreland basin). Thereafter, the stratigraphic succession underwent deformation which led to its prolonged subaerial exposure and rubefaction. In Permian times, a marine transgression gave rise to the Del Salto Formation (600 m), which is constituted by beach deposits with some aeolian reworking and which lies unconformably over the Lower Carboniferous rocks. Conglomerates (Quebrada del Alumbre Formation, $100 \mathrm{~m}$ ) produced by an alluvial system prograded episodically into coastal areas. The Escombrera Formation $(350 \mathrm{~m})$ is composed of beach deposits prograding seawards. This formation probably represents the end of the Palaeozoic sedimentary record. Thereafter, a playa-lake and an alluvial fan system were generated (Quebrada de la Arena Formation). This unit $(750 \mathrm{~m})$ was the last infill of the Gondwanan retroarc foreland, the total thickness of which was about $4000 \mathrm{~m}$.
\end{abstract}

Keywords: Lithostratigraphic units, Carboniferous, Permian, Triassic, Chanic orogen, Gondwanan orogen, Andes

\section{Resumen}

Se presentan nuevos datos sobre las unidades neopaleozoicas aflorantes en la parte occidental de la Precordillera andina. Esas unidades litoestratigráficas estan separadas por dos discordancias angulares principales asociadas al desarrollo de las orogenias Chánica (Devónico tardío-Carbonífero temprano) y Gondwánica (Carbonífero tardío-Pérmico temprano) respectivamente. Otra nueva discordancia sugiere el inicio del ciclo andino durante el Pérmico medio. La Formación Del Ratón $(800 \mathrm{~m})$ está constituida principalmente por conglomerados y puede dividirse en dos unidades de rango menor: la parte basal y la parte superior respectivamente. La parte basal (Miembro inferior) fue acumulada en un fiordo. La parte superior (Miembro superior) fue generada en un sistema alluvial dominado predominantemente por la acumulación de capas planas de alto régimen de flujo, mientras que la parte más alta fue depositada en un entorno de abanico deltaico (fan 
delta). La procedencia de los clastos y las paleocorrientes principales indican la presencia de un relieve topográfico alto y significativo, situado al O y NO de los afloramientos actuales.La Formación El Planchón (1400 m) constituida principalmente por lutitas y areniscas fue acumulada en un contexto de abanico submarino (deep-sea fan). Estos materiales predominantemente lutíticos pasan lateralmente hacia el norte a conglomerados acumulados en un ambiente sedimentario glacial. Las Formaciones Del Ratón y El Planchón corresponden a la sedimentación sinorogénica Chánica (cuenca de antepaís chánica). Posteriormente, la sucesión estratigráfica sufrió una deformación que dió lugar a una prolongada exposición subaérea y su consiguiente rubefacción. Durante el Pérmico, una transgresión marina produjo la acumulación de la Formación Del Salto $(600 \mathrm{~m})$, que está constituída por depósitos de playa con algún retrabajamiento eólico y que recubre discordantemente los materiales del Carbonífero inferior. Un sistema aluvial conglomerático (Formación Quebrada del Alumbre $100 \mathrm{~m}$ ) pogradó episódicamente sobre las zonas costeras. La Formación Escombrera $(350 \mathrm{~m})$, que está constituída por materiales arenosos costeros progradantes hacia el mar, representa, muy probablemente, el final del registro sedimentario paleozoico en esta zona. Posteriormente se generó otra discordancia sobre la que se acumularon materiales arenosos en un contexto de cursos fluviales trenzados sobre los que se disponen materiales lutíticos acumulados en una ciénaga (playa-lake) que gradan, primero a cursos trenzados, luego a cursos sinousos y finalmente a abanicos aluviales (Formación Quebrada de la Arena). Esta unidad $(750 \mathrm{~m}$ ) corresponde al último relleno sedimentario de la cuenca Gondwánica de retroarco, cuya potencia es del orden de unos $4000 \mathrm{~m}$..

Palabras clave: Unidades litoestratigráficas, Carbonífero, Pérmico, Triásico, Orogenias Chánica, Orogenia Gondwánica, Andes

\section{Introduction}

This work is focused on some neopalaeozoic lithostratigraphic units of the central sector of the Argentinean Precordillera. Although the Del Ratón, El Planchón and Del Salto stratigraphic units have been studied for many years (Heim, 1952; Guerstein et al., 1965; Quartino et al., 1971; Manceñido, 1973; Venturini, 1980; Sessarego, 1983; De Rosa, 1983; Sellés Martínez, 1985; Archangelsky, 1987, 1996; Sessarego and Césari, 1989; Etchichury et al., 1990; Barredo and Stipanicic, 2002), there is a dearth of reliable data about the accumulation of their materials. Nevertheless, significant advances have been made in the structure of the area (Astini et al., 1996; Alonso et al., 2005a, b; 2008) and in the definition of the ages of these formations and their stratigraphic equivalents (Limarino and Césari, 1992; Barredo et al., 2012;
Colombo et al., 2012; Limarino et al., 2012). However, certain misconceptions have been attributed to implausible data obtained from fossil remains identified as Devonian (Kerlleñevich, 1967; 1969), data which have consequently never been cited in recent studies of the area. These inaccuracies have given rise to significant problems concerning the stratigraphic location of the El Planchón Formation and related units (Amenábar and di Pasquo, 2008).

The present work seeks to provide some answers to the problems arising from the stratigraphy of the upper Palaeozoic rocks that crop out in the proximity of km 114 of the Ruta Nacional 20 (National 20 highway) in the Argentine Precordillera (San Juan Province, Figs. 1, 2). The literature of the area has been revised and some misconceptions concerning the main lithostratigraphic units, the depositional interpretations and also some chronostratigraphic attributions have

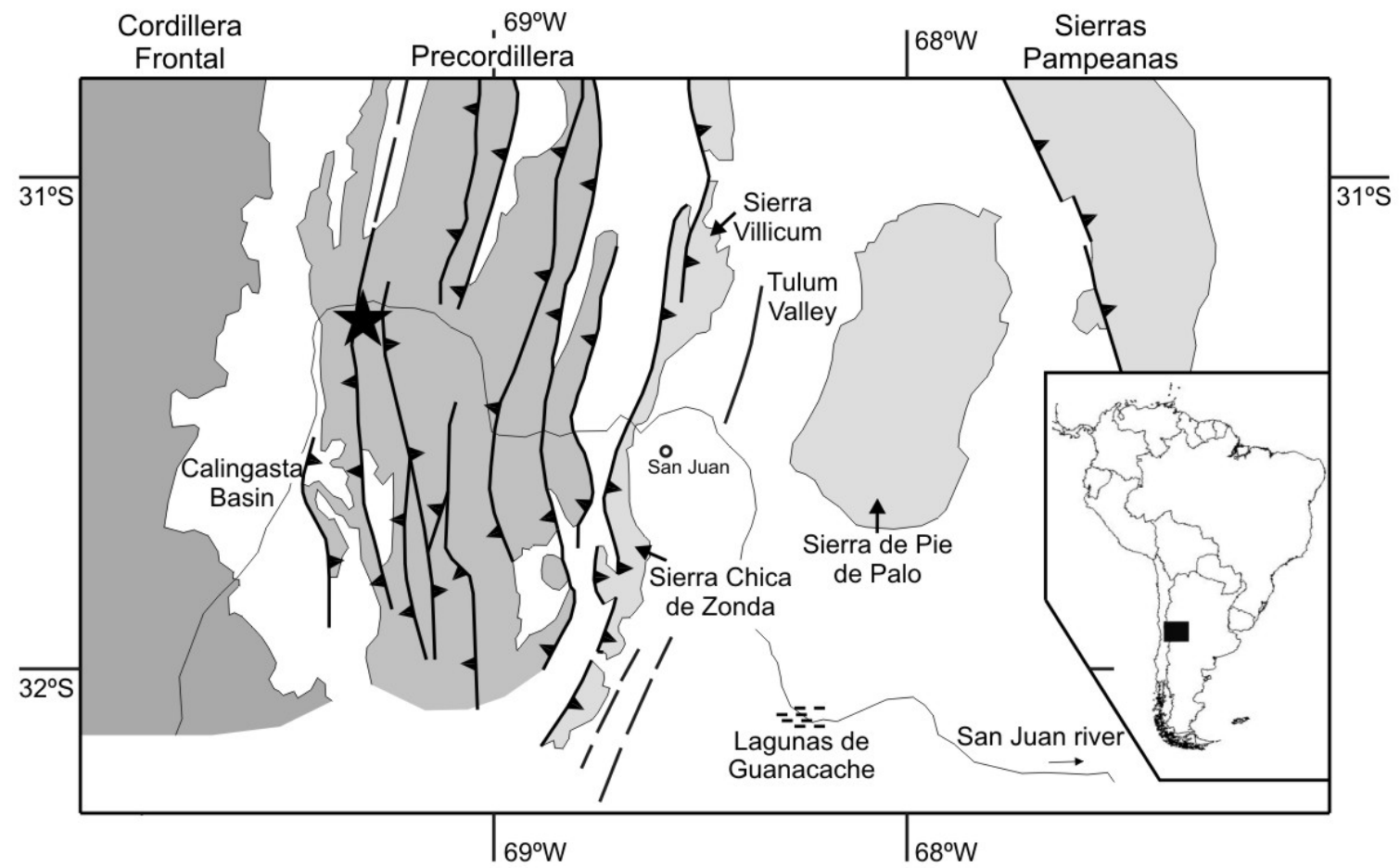

Fig. 1.- Star indicates the location of the study area. 


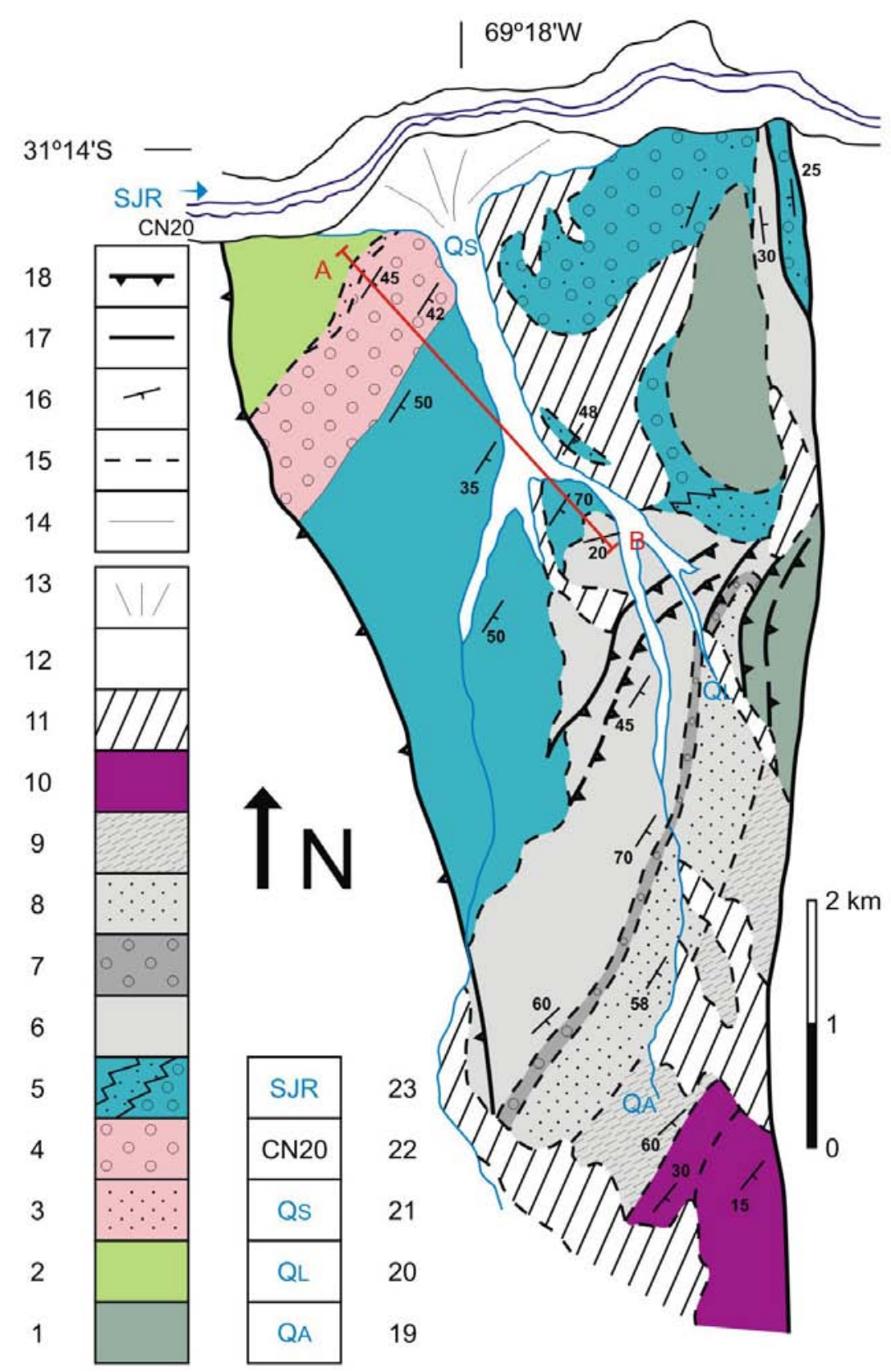

Fig. 2.- Schematic geological map of the study area. The main lithostratigraphic units are as follows: 1) Alcaparrosa Formation. Ordovician; 2) Codo Formation. Devonian basement; 3) Del Ratón Formation, Lower member. Lower Carboniferous; 4) Del Ratón Formation, Upper Member. Lower Carboniferous; 5) El Planchón Formation. Lower Carboniferous (?); conglomerates; sandstones; shales; 6) Del Salto Formation. Lower Permian; 7) Quebrada del Alumbre Formation. Middle Permian ; 8) Escombrera Formation. Upper Permian (?); 9) Quebrada de la Arena Formation. Middle Triassic ; 10) Rincón Blanco Group, Upper Triassic (?); 11), Quaternary consolidated; 12) Quaternary unconsolidated; 13) Quaternary alluvial fan of the Quebrada del Salto; 14) Normal stratigraphic contact; 15) Unconformity and/ or smooth erosive surface; 16) Dip and strike; 17) Fault; 18) Overthrust; 19) QA, Quebrada de la Arena; 20) QL, Quebrada del Alumbre; 21) QS, Quebrada del Salto; 22) National 20 Road; 23) SJR, San Juan River. been cleared up. We present a schematic geological cartography of the study area. Some detailed stratigraphic sections of the main lithostratigraphic units have been studied together with the data provided by primary sedimentary structures, enabling us to interpret their sedimentology. A number of the formerly established lithostratigraphic units have also been revisited, resulting in the reorganisation of some lithostratigraphic units. At the same time, the unconformities which play a significant role in the regional correlation have also been differentiated (Fig. 3).

\section{Lithostratigraphic units}

The main stratigraphic units are usually limited by unconformities in the study area. There are a few exceptions such as the case of the basal limit of the El Planchón Formation, which overlies the Del Ratón Formation with a normal stratigraphic contact as a result of sedimentation. The lithology and stratigraphic relationships of each of the Late Paleozoic deposited units outcropping in the region as well as their depositional palaeoenvironments are described below.

\subsection{Del Ratón Formation (Guerstein et al., 1965)}

Carboniferous conglomerates resting on Devonian rocks (Fig. 4) by means of an angular unconformity (D1) crop out in two areas. The best known outcrops containing plant remains correspond to the exposures along the left bank of the Quebrada Del Salto creek near its confluence with the San Juan River. Another group of Carboniferous conglomerates 


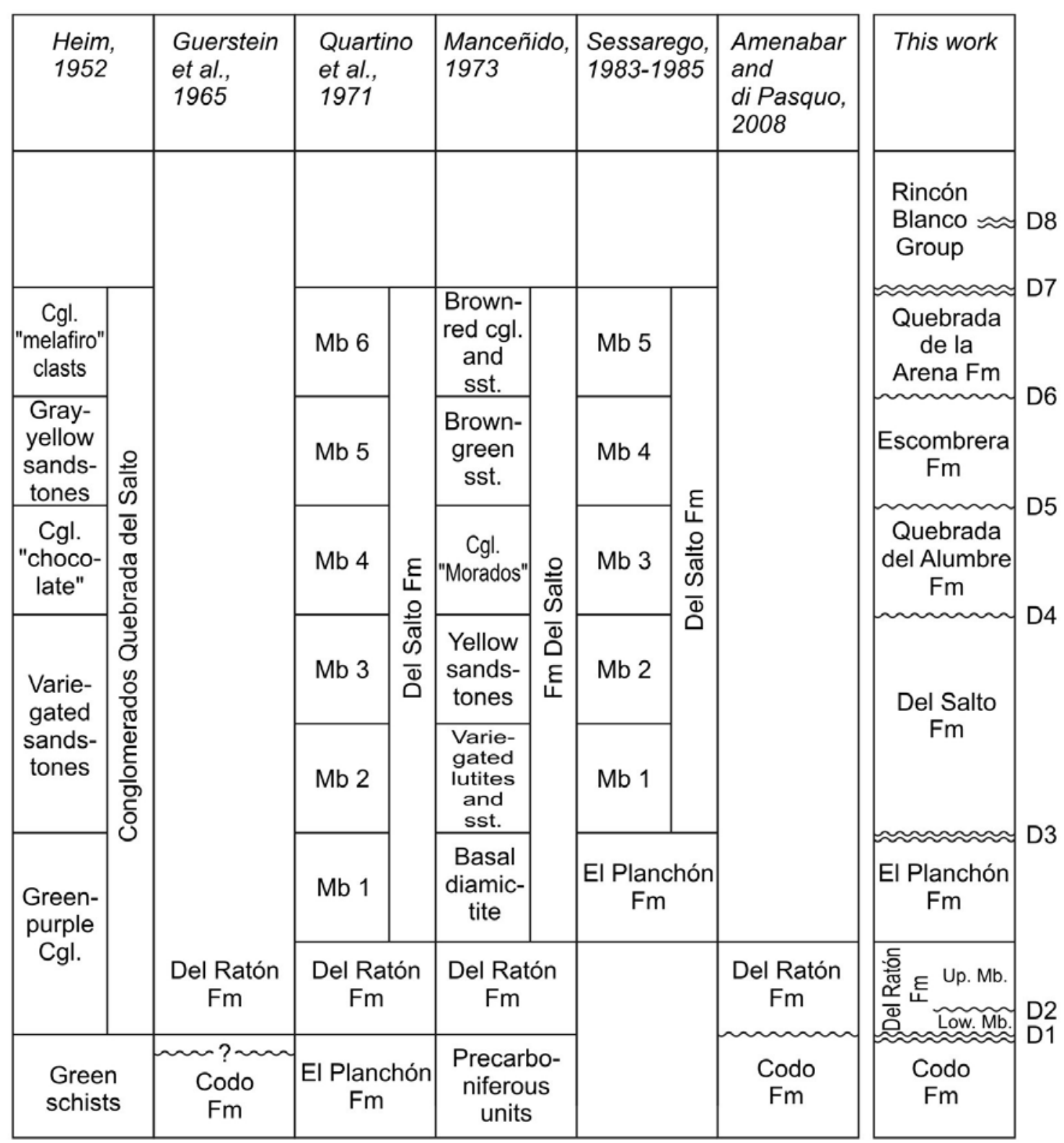

Fig. 3.- Equivalences of the main lithostratigraphic units in the study area. The main unconformities and/or smooth erosive surfaces can be observed (D1-D8). Some are angular (D1, D3, D7 and D8) others are markedly erosive (D4) whereas the rest are smooth erosive surfaces (D2, D5 and D6). The D1 unconformity marks the start of the Chanic orogeny, the D3 the start of the Gondwanic orogeny and the D4 probably the beginning of the Andean cycle.

is present in the northern margin of the San Juan River where the sequence is partially covered by Quaternary sediments. Two members are identified given the significant lithological differences exhibited by the Del Ratón Formation from base to top. The unit rests on the Devonian sedimentary succession with an angular unconformity (D1). Two units may be distinguished:

Lower Member: This is a conglomeratic unit with an approximately lenticular geometry and an erosive base that is evidenced by a pavement of disorganised and polymodal $(30-50 \mathrm{~cm})$ granitic clasts. Two sections (A and B) with a total thickness of $85-100 \mathrm{~m}$ can be differentiated. The lower section section (A) consists of metric-thick stacked beds of massive matrix-supported conglomerates which in some

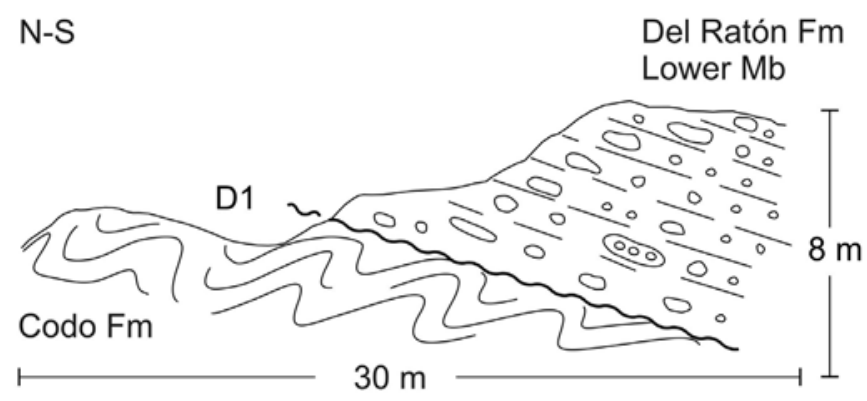

Fig. 4.- Angular unconformity over the Devonian Codo Formation that underlies the basal levels of the Del Ratón Formation Lower Member. 

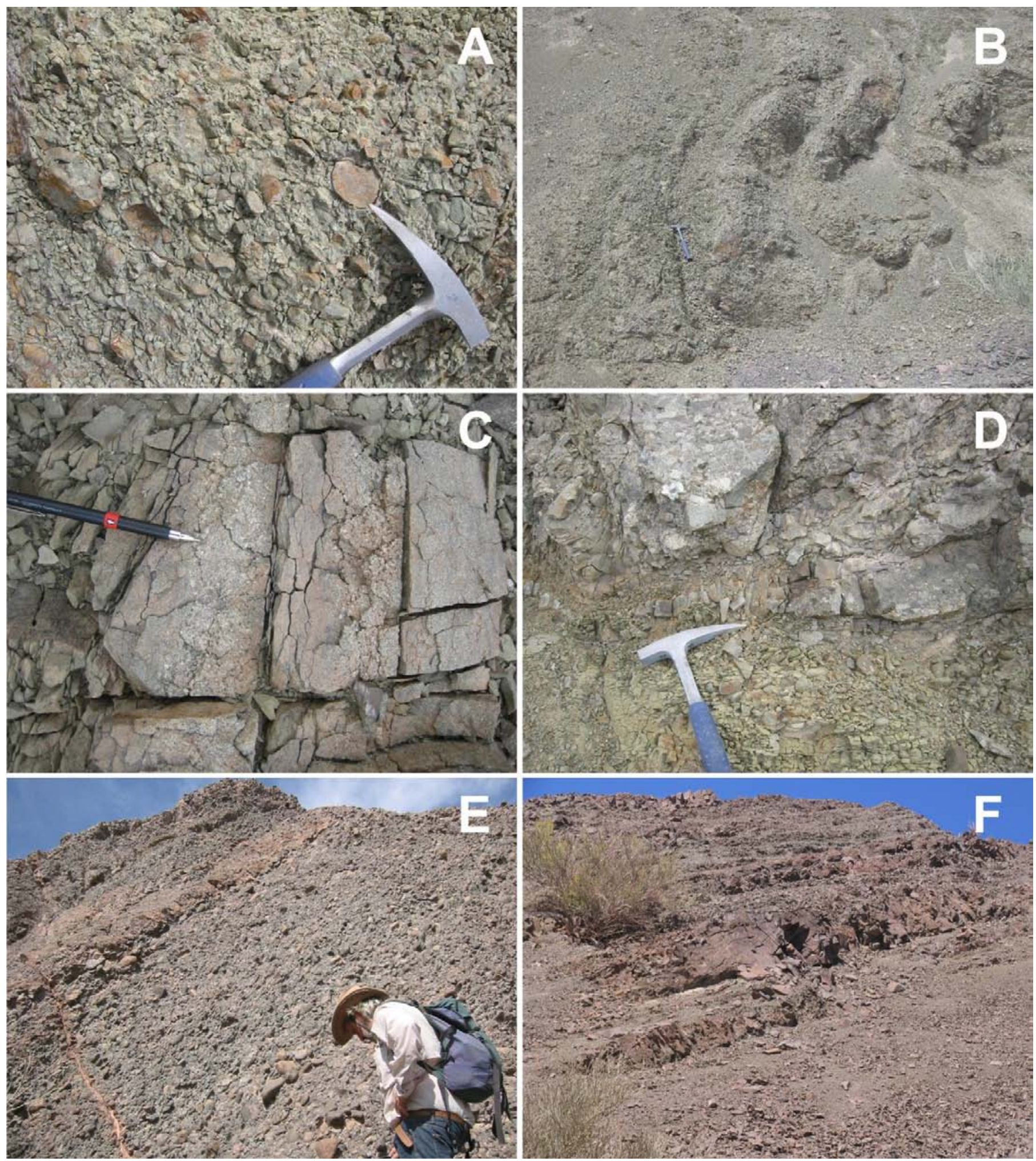

Fig. 5.- A) Close-up of the pebbly mudstone facies. Del Ratón Formation section A of the Lower Member; B) Deformed pebbly mudstone deposits. Del Ratón Formation section A of the Lower Member; C) Small coarsening-upwards sequences. The pencil tip indicates the normal polarity; D) Close-up of the clinoform (foreset) of the small delta in the conglomeratic levels of the Lower member of the Del Ratón Formation section B; E) Conglomeratic facies. Del Ratón Formation. Upper Member; F) Summit of the Del Ratón Formation. Upper Mb. There are some episodes of stream mouth bar deposits in the fan delta depositional setting.

cases grade to massive pebbly mudstones (Fig. 5A) locally deformed (Fig. 5b).The clasts, which are subrounded to rounded and vary in size from 3 to $5 \mathrm{~cm}$, are predominantly composed of granite $(70 \%)$ and metamorphic rocks $(20 \%)$ whereas the rest are greywackes and carbonates $(10 \%)$. Several discontinuous horizons with very coarse clasts (30- 


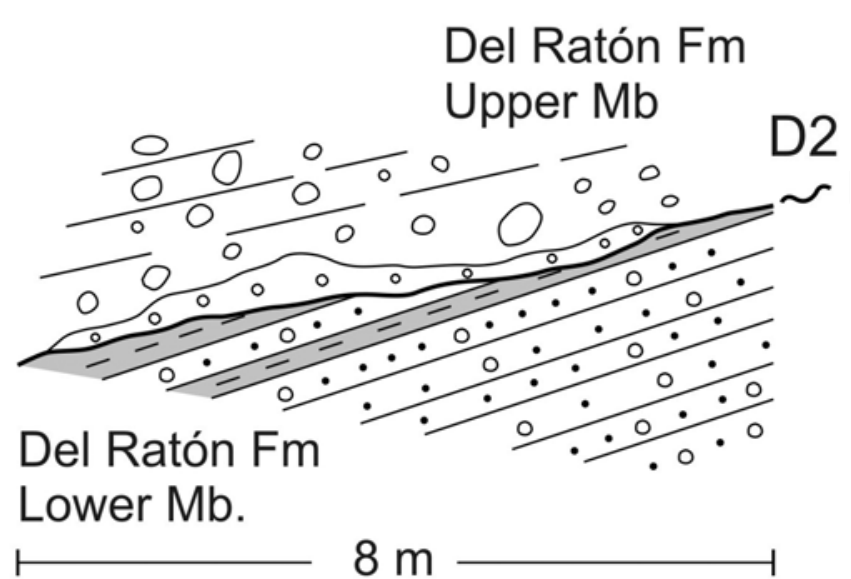

Fig. 6. - Smooth erosive unconformity in the Del Ratón Formation. This is the contact between the two members.

$40 \mathrm{~cm}$ ) are interfingered with shales bearing plant remains (coal). Some conglomeratic and shale levels with out-sized clasts are interpreted as dropstones. There are some sandstone levels displaying undulated cross-bedding. The upper section (B) is composed of cross-bedded conglomerates (up to 1.5 $m$ thick) that sporadically show intercalations of coarse- and medium-grained sandstones. Small grooves were identified at the base of some conglomerate beds, indicating NNW-SSE palaeocurrents.

Several conglomeratic horizons display small scale crosslaminations. Some levels of conglomeratic sandstones present thin coarsening upward sequences locally (Fig. 5C). Section $\mathrm{B}$, which shows a thickening upwards trend, culminates in metric cross-stratified conglomeratic levels. A smooth erosive surface (D2) is present at the summit.

Interpretation: The texture of the deposits suggests massive flows with some reworked clasts (second generation). The synsedimentary deformation indicates that the accumulation processes developed in areas with steep slopes with basement instability. Section A represents the subaqueous transport of gravelly massive flows with preservation of organic matter (coal). The undulate cross-bedding strongly suggests that some conglomeratic levels were reworked by wave action. In section B, the coarsening upwards sandy bodies (traction carpets) were probably generated by the dilution of very dense turbulent flows (hyperpicnic). The upper conglomerates would correspond to the progradation of gravelly bars in a shallow and small deltaic setting (Fig. 5D). In this context, the thin lamination of the shales is probably attributed to the flocculation of mud-rich flows within a water body with varying salinity. Thus, the accumulation in a fjord environment (Boulton et al., 2001; Evans, 2003; Iverson and Iverson, 2001; Powell, 2003) cannot be ruled out because of the presence of dropstones, synsedimentary large-scale deformation and hyperpicnic flow deposits, According to Amenábar and Di Pasquo (2008), these materials accumulated during the Lower Carboniferous.
Upper Member: The Upper Member rests on a smooth erosive surface (D2), and mainly corresponds to orthoconglomerates (Fig. 6) and coarse-grained sandstones (up to 700 $\mathrm{m}$ thick). The stratigraphic significance of the surface that separates the Lower and Upper Members of the Del Ratón Formation should be evaluated in the future from a regional perspective in order to ascertain whether this surface is associated with significant changes in the palaeogeography of the basin. Conglomerate clasts are dominated by sandstones (65\%, chiefly greywackes), granites and rhyolites $(30 \%)$ and scarce quartz and metamorphic rocks (5\%). The relatively high proportion of rhyolitic and granitic clasts gives a reddish colour to the coarse-grained beds. The sandstone intercalations have a grain-size ranging from coarse to very coarse. The sandy matrix is poorly sorted whereas the clasts are very rounded and clearly aligned. A number of dispersed clasts $(3-5 \mathrm{~cm})$ are present locally. Conglomeratic unitary sequences, which have thicknesses of about of 3 - $4 \mathrm{~m}$, display plane beds enhanced by clast lineations (Fig. 5E). Some levels show a large number of clasts of pink granite $(40 \%)$ locally. The sandy materials are interfingered with poorly sorted and disorganised conglomeratic levels which display some imbricated clasts locally, indicating E-W oriented currents. Poorly sorted conglomeratic levels evidenced by planar clast alignments consist of coarse red granites and rhyolites (40-50 $\mathrm{cm})$ locally. Some conglomeratic levels show clast lineations which indicate SE-NW oriented currents. The uppermost thick sandstone levels display cross-stratification generated by hydraulic dunes, indicating palaeocurrents from the $\mathrm{W}$ and WNW. The top of the conglomeratic section, with a thickness of about $125-130 \mathrm{~m}$ is characterised by levels showing different types of middle and small scale cross bedding (Fig. 5F). Several bodies are lenticular whereas others with a stratiform morphology are interfingered with shales and sandstones with undulated lamination (wavy).

Interpretation: The Upper member of the Del Ratón Formation accumulated in an alluvial depositional system that was predominantly characterised by gravels carried by upper flow regime currents. Flows transported sandy materials by means of bars and hydraulic dunes in the upper part of some conglomerate sections. The alluvial system finally evolved into a fan delta in a coastal setting as evidenced by different mouth bar sequences. The clastic accumulation is the sedimentary response to the erosion of the Protoprecordillera generated during the Chanic orogeny (Heredia et al., 2012).

The age of the unit is provided by the chronostratigraphic vertical distribution of some organic remnants found in the Lower Member (Sessarego and Cesari, 1989; Amenabar and Di Pasquo, 2008) whereas the Upper Member displays a conspicuous absence of fossils. The study of a large clast of granite (Fig. 14, site 1), which belongs to the basal pavement of the Lower Member, yields an absolute chronology (Gallastegui et al., this volume) of $348 \pm 2 \mathrm{Ma}$ (U-Pb zircon data). Thus, the granite was generated during the Lower Missippian near the Tournaisian-Visean limit, whereas the sedimentary 

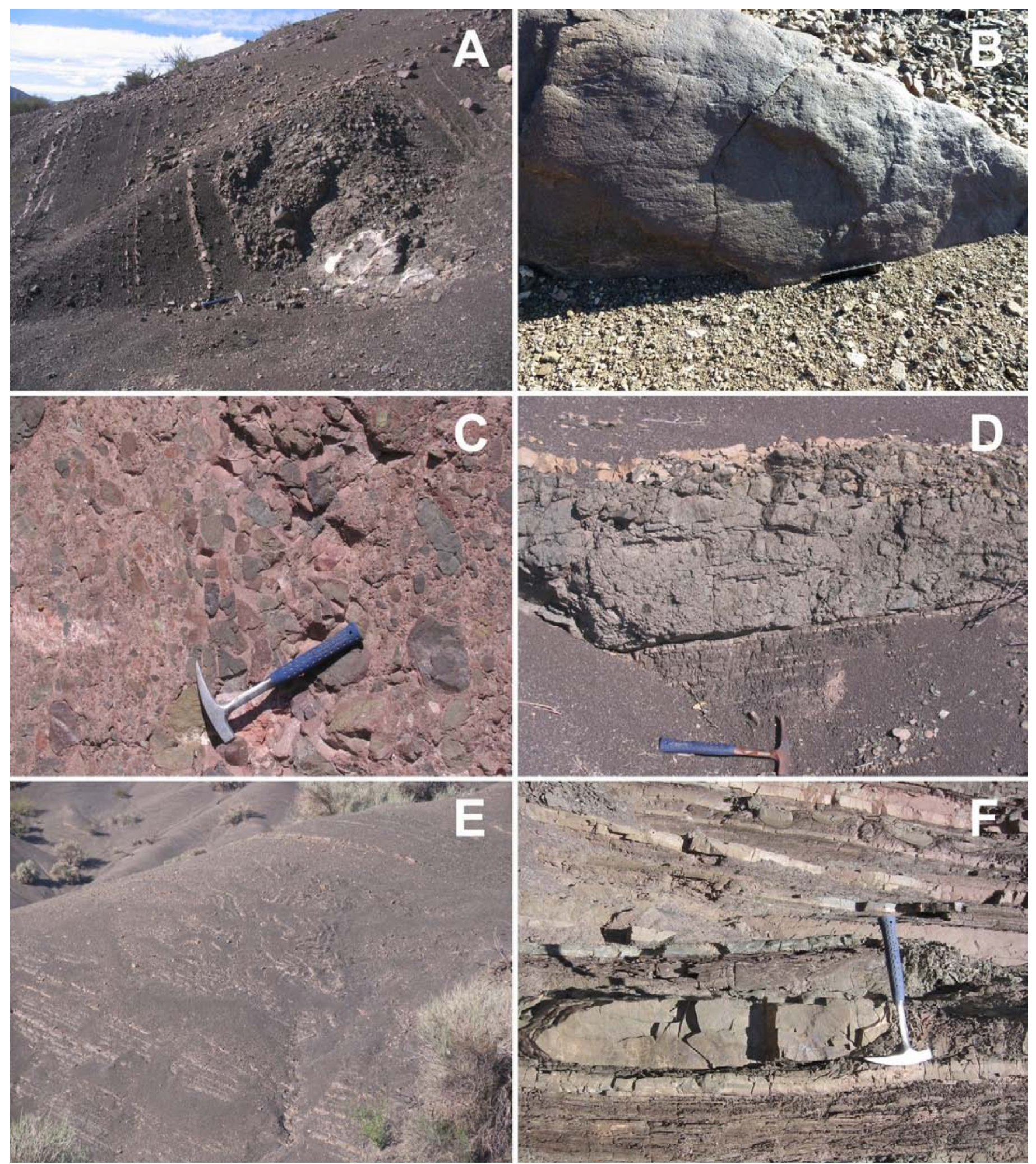

Fig. 7. - The El Planchón Formation. A) Conglomerate level (dumped tillite block?) intercalated with the lutitic materials; B) Striated clast in the conglomerates. Scale: $5 \mathrm{~cm}$ in length; C) Close-up of the conglomerates cropping out near the N 20 road; D) Small conglomeratic channel; E) Slumped lutitic materials; F) Turbiditic sandstone level affected by a differential load (boudinage).

accumulation of this granitic clast in the Del Ratón Formation was more recent, Visean or younger. Moreover, pollen and spores found in section A of the Lower Member provide ample evidence that the conglomerates were deposited during the Lower Visean (Azcuy et al., 1981; Amenabar and di Pasquo, 2008). 


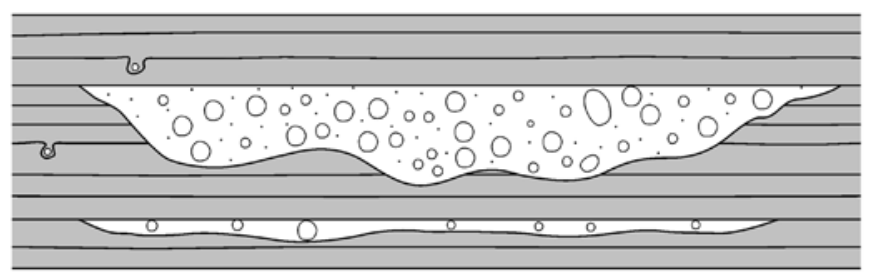

$2 \mathrm{~m}[$

Figure. 8.- Schematic disposition of the small intercalation of conglomeratic levels in the turbiditic mudrocks of the El Planchón Fm. Dropstone deformations can be observed.

\section{2._El Planchón Formation (Quartino et al., 1971)}

This unit is about $1300-1400 \mathrm{~m}$ thick and is made up of alternating shales and sandstones that crop out along the Quebrada Del Salto, with synsedimentary deformations in the whole section, increasing towards the top (Fig. 7E). Sandy materials with a fine to medium grain-size are well sorted, displaying several cross-laminations and basal marks that indicate NW-SE palaeocurrents. Polygenic and polymodal conglomerates change laterally to more muddy materials towards the $\mathrm{S}$ and $\mathrm{E}$ (Figs. 7C, 7D). Shale and sandstone layers are distorted by some dropstones locally (Fig. 8). The upper part of the unit is strongly reddening below a marked angular unconformity (D3).

Interpretation: The shales and sandstones are arranged in decimetric Bouma-type sequences, Tc-e and Tb-e. They suggest that these materials were deposited by turbidity flows in a deep and relatively narrow N-S oriented marine basin. The interfingered coarse-grained levels (Fig. 9) display facies of poorly sorted, matrix supported and disorganised conglomerates, suggesting that these materials were transported and de- posited by different mass flow (debris flow) episodes. These rocks are interfingered with the shales that graded laterally into conglomerates that were deposited coevally in a marine environment. The presence of some striated clasts and deformations produced by dropstones indicates that the deposition occurred in a glacial setting. The conglomerates filled the $\mathrm{N}-\mathrm{S}$ aligned palaeovalley with contributions mainly from the $\mathrm{N}$ and the E. A number of turbiditic episodes in a deep water context led to several synsedimentary slumps due to the high detrital input on unstable slopes. The strongly reddening of the top of the unit probably corresponds to an episode of intense chemical alteration because of prolonged subaerial exposure.

\section{3._Del Salto Formation (Quartino et al., 1971)}

Yellowish cross-stratified sandstones (Sessarego, 1983) overlying an angular unconformity (D3) accumulated during the early Permian (Manceñido, 1973; Taboada, 2006a, b). A thick sandstone level characterised by several middle-scale cross-stratifications displays some intercalations (Fig. 10) of shales and sandstones with different types of cross-stratification and cross-lamination (hydraulic dunes and ripples respectively). The fossil (brachiopoda) associations (Manceñido, 1973; Manceñido and Sabattini, 1974; Manceñido et al., 1976a, b) distributed in the shales are Aselian (Taboada, personal communication) i.e. Cisuralian (Lower Permian). Some coarsening and thickening upwards sequences are present towards the upper part of the unit. The base of the upper third of this section consists of cross-stratified sandstones (dipping towards the $\mathrm{S}$ and $\mathrm{SE}$ ) which evolved into planar beds. The tops of some sequences are characterised by large-scale trough cross bedding. The unit is about 550-600 $\mathrm{m}$ thick. The whole section is arranged into more than seven megasequences that are clearly differentiated in the outcrop.

B Section A

SE-NW

Del Salto Fm

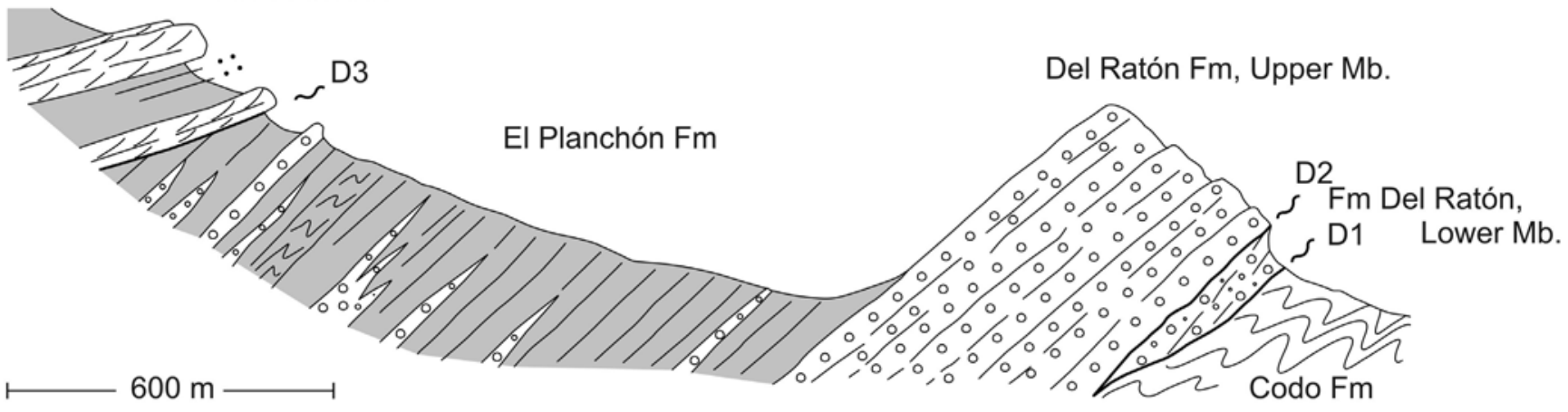

Fig. 9.- General distribution of the main lithostratigraphic units displayed in the lower part of the section. Cross section (A-B) indicated in figure 2. 

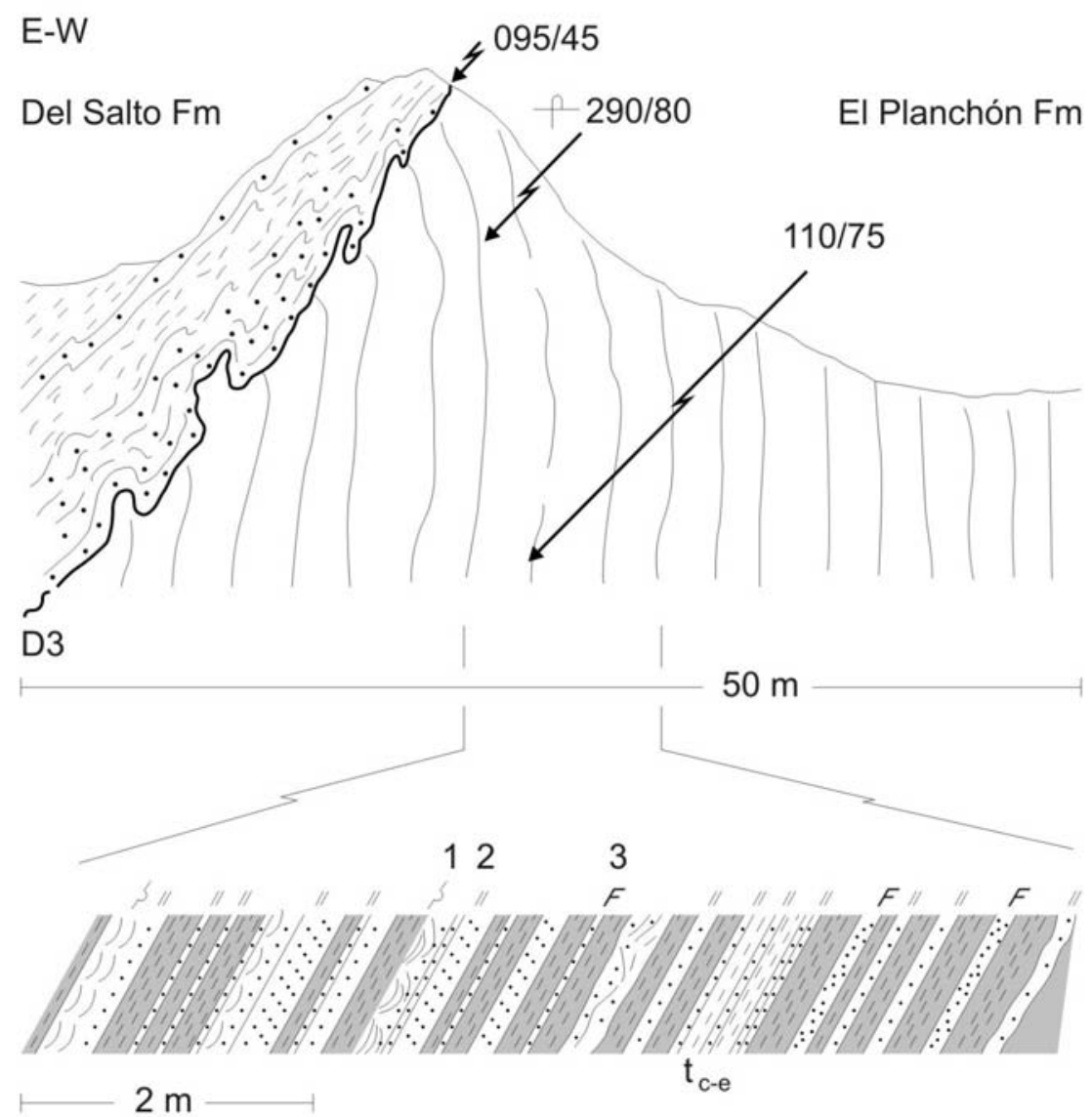

Fig. 10.- Basal levels of the Del Salto Formation over a prominent and folded angular unconformity. Several turbiditic levels (tc-e) of the El Planchón Fm are displayed. Some have basal deformations (1), others have parallel laminations (2) whereas the rest display $(\mathrm{F})$ ripple-like cross laminations (3).
These display green and grey mudrocks at the base. Towards the top, they grade into thick sandstone levels with different types of medium-scale cross bedding and large cross-stratification. In the upper part only large cross-stratified sets were identified locally. A very small number of sequences with coarsening-upwards arrangements are present at the top of the unit (Fig. 11).

Interpretation: Sandy levels, generated by coastal bars with their tops reworked by waves, controlled restricted areas where large populations of brachiopods developed. At large scale, the sandy materials are arranged in a number of coarseningupward macrosequences. These sequences start with levels of shaly materials, and are interpreted as having been deposited in an offshore environment that onlapped sandy shoreface levels and culminated in aeolian dunes locally. Some large crossbedded planar layers probably corresponded to a foreshore, indicating that the open sea was to the S and SE. Thus, after an initial sea-level rise, resulting in an offshore environment, a

\section{$\mathrm{S}-\mathrm{N}$}

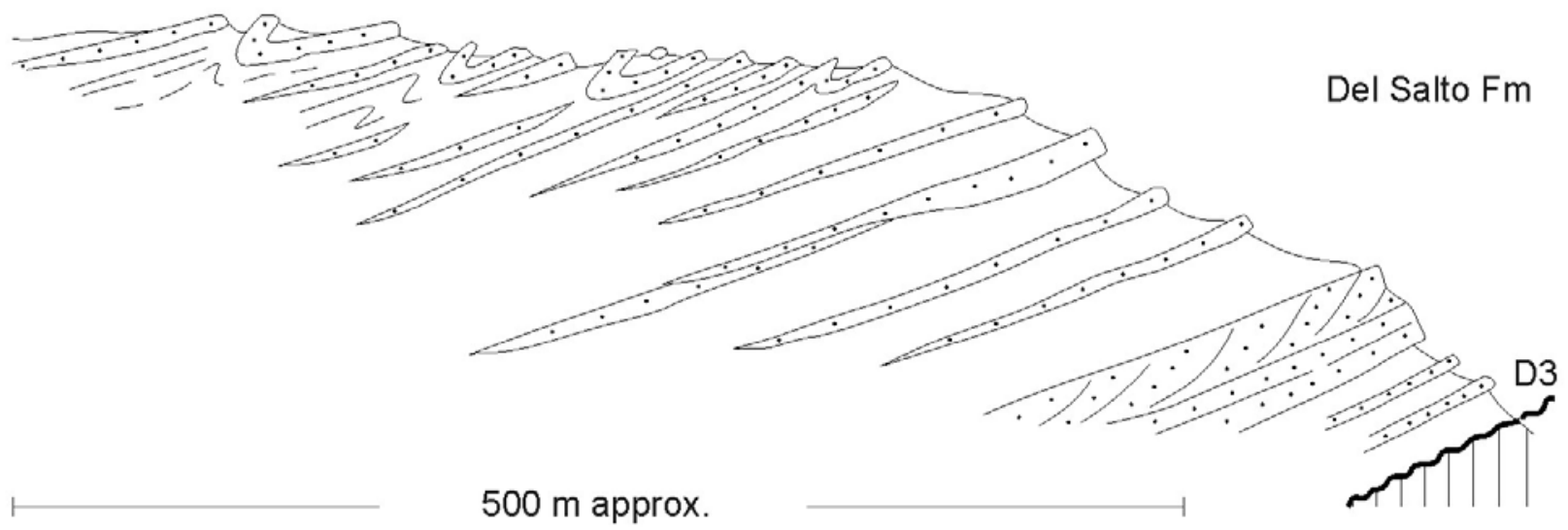

Fig. 11. - Basal section of the Del Salto Formation. Distribution of the different levels of sandy bars and small channels interfingered with shales. 


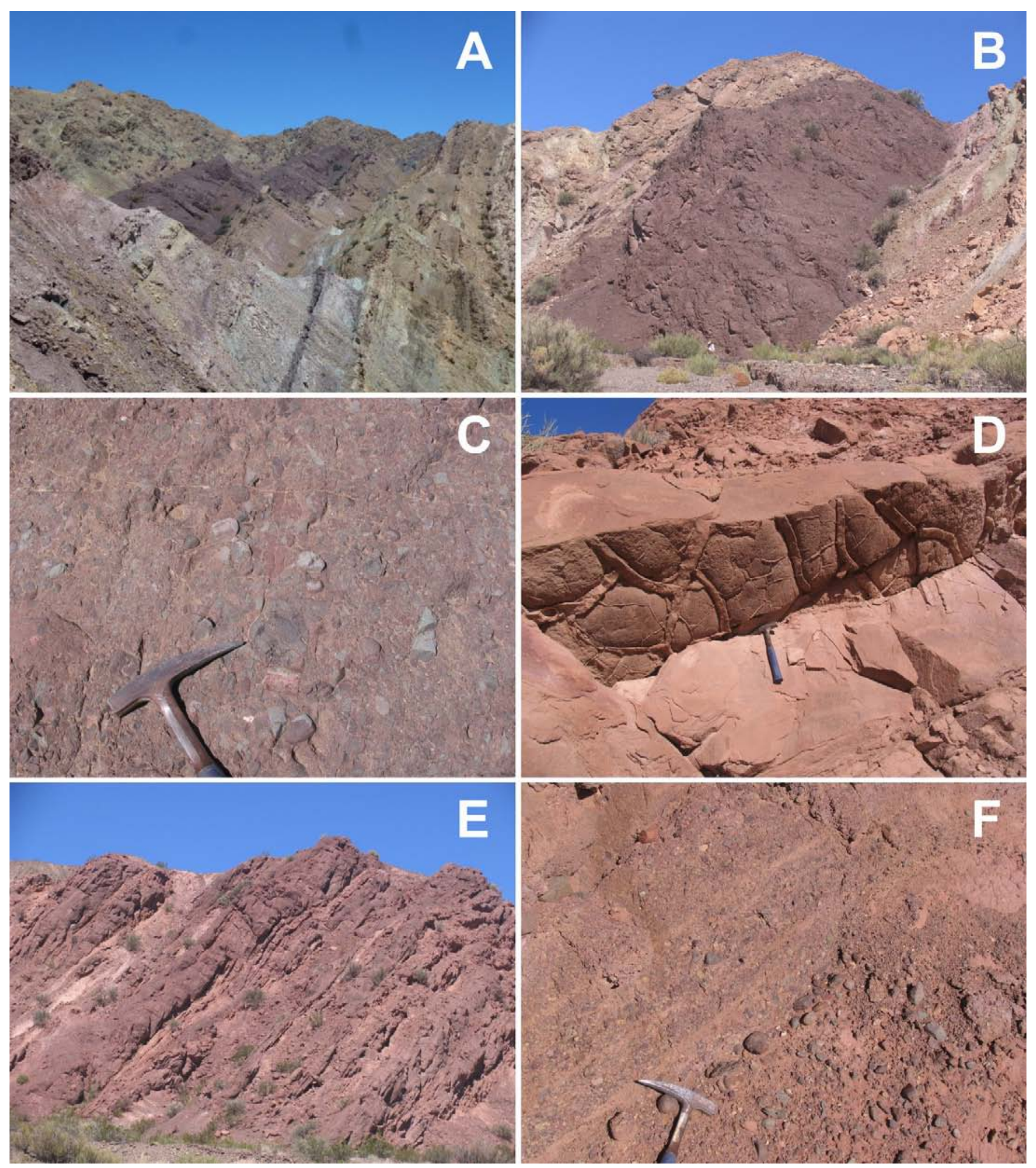

Fig. 12.- Quebrada del Alumbre Formation: A) Outcrop in the upper part of Quebrada del Salto; B) Distribution of the unit towards the south; C) Close-up of the conglomerate facies. Quebrada de la Arena Formation: D) Middle Mb. Mud crak casts; E) Upper Mb. Coarse-grained point bars; F) Pebbly sandstones facies in braided channels in the basal part of the upper Member.

shallowing event gave rise to shoreface sandy accumulations. This system tract, which underwent significant variations in the sea-level, was repeated at least seven times in this area.
The Del Salto Formation ends in an erosive unconformity which supports the overlying unit. 


\subsection{Quebrada del Alumbre Formation (new unit)}

This is a new definition of the older non-formal lithostratigraphic unit known as Conglomerados "chocolate" (Heim 1952) or Conglomerados Morados (Manceñido, 1973) by the authors working in the area. The new denomination is derived from neighbouring Quebrada del Alumbre located in the area where the unit crops out (Fig. 12).

The Formation is made up of purple polygenic and polymodal conglomerates with a poorly-sorted sandy matrix supported fabric displaying a variable crude cross-stratification. The clasts, which are usually subrounded, consist of volcanic rocks $(80 \%)$, reddish sandstone, greywackes and quartz. Some of them are of the second generation. The Formation overlies the Del Salto Formation with an erosive unconformity (D4). It has a regional lenticular geometry with a thickness of around $60-75 \mathrm{~m}$ to the north, and attains a maximum thickness of about 100-125 m to the south (Figs. 12A, 12B).

Interpretation: The matrix-supported fabric suggests that the conglomerates were initially deposited by debris-flow episodes in a sub-aerial context as evidenced by the red colouring. In several cases, some cross-stratifications indicate that the sediment was transported by a variety of bars in a braided context. The facies arrangement and the scarce palaeocurrents to the W and SW suggest that these materials resulted from the progradation of an alluvial fan that prograded from the $\mathrm{N}$ and NE to the S and SW (Fig. 13). The study of a thin andesitic level (Fig. 14, site 2) yields an absolute chronology between $289 \pm 4 \mathrm{Ma}$ and $293 \pm 5 \mathrm{Ma}$ (U-Pb zircon data). Thus, the unit accumulated near the limit between the Lower Artinskian and the Upper Sakmarian, Cisuralian, Permian.

\subsection{Escombrera Formation (new unit)}

The basal part is mainly composed of yellow-grey sandstones in metric and decimetric units which display some volcanic clasts reworked from the underlying Quebrada del Alumbre unit. The new denomination is derived from neighbouring "Escombrera" (mine-waste deposit) generated by the activity of the former aluminium sulphide mine owned by the IMSA Company in the area where the unit crops out. The sandstones are arranged at large scale in more than four megasequences with a total thickness of about $320-350 \mathrm{~m}$. These sequences usually start with a green-grey shaly section. Towards the upper part of each sequence is an intercalation of some thin sandstone levels and shales which characterise a heterolitic section. Some thick sandstone levels with medium-scale cross bedding are present at the top. In the upper part of the unit is a white-coloured level which displays a large number of feldspar grains in the sandstones. In some cases, large sets of cross-bedding are present at the top of the minor units. Towards the upper part of the unit are several levels of sandstones that are intercalated with shales and are distinguished by medium-scale cross bedding and smallscale cross-laminations locally (Fig. 14).

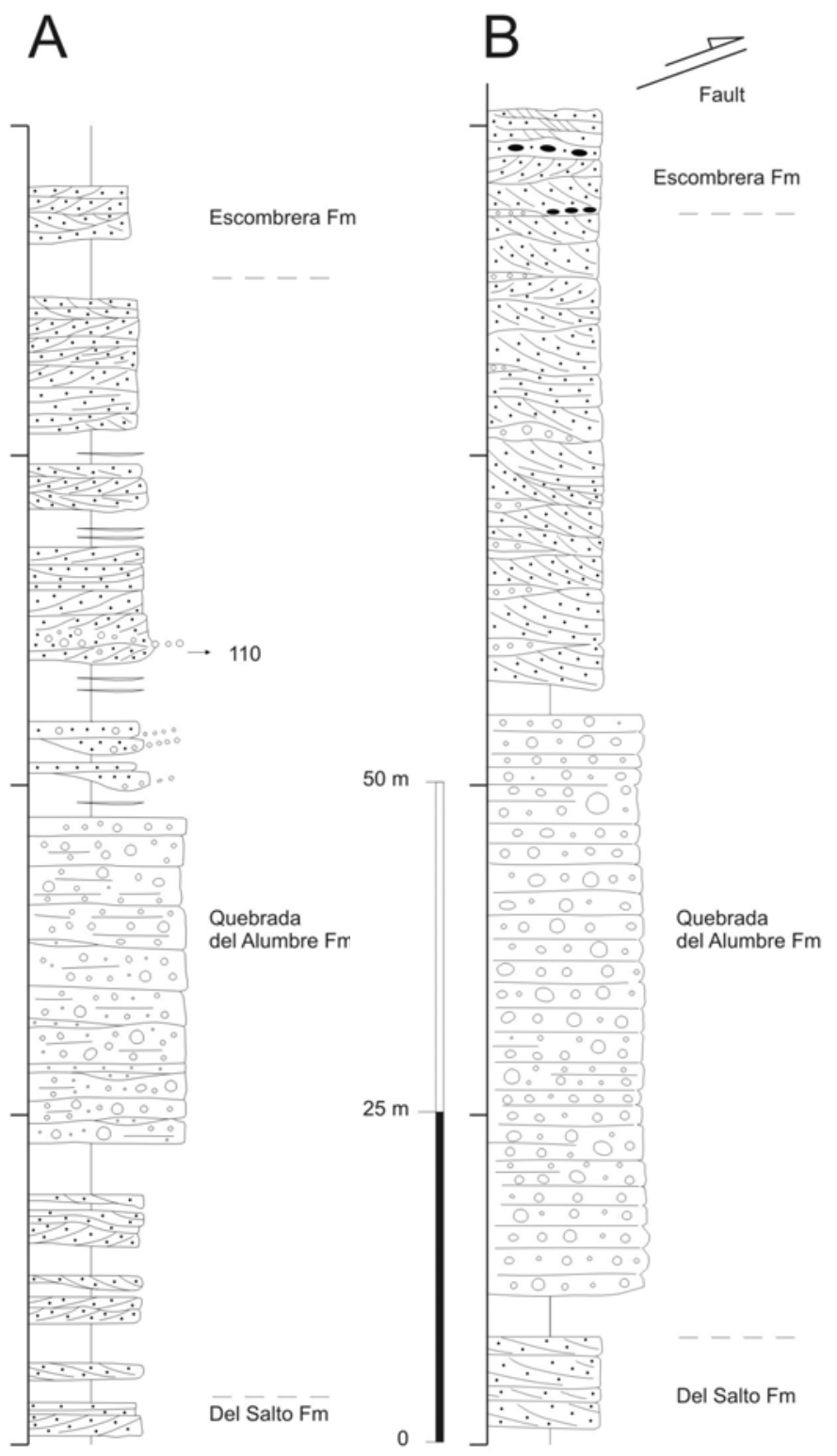

Fig. 13.- Quebrada del Alumbre Formation stratigraphic logs; A) situated at $31^{\circ} 17^{\prime} 42.39^{\prime \prime} \mathrm{S}, 69^{\circ} 17^{\prime} 09.40^{\prime \prime} \mathrm{W}$; B) situated at $31^{\circ} 18^{\prime}$ 26.87'S, 69 $17^{\circ}$ ' 15.77'W.

Interpretation: The upper member was probably deposited in transitional, coastal and continental environments. The shales corresponded to the deepest accumulations and accumulated in an offshore-dominated environment. This environment was controlled by a significant rise in sea-level. By contrast, the sandstones which display many primary sedimentary structures (megaripples, bars and sub aquatic dunes) accumulated in a non-confined hydraulic setting in a relatively shallow coastal environment (Fig. 15). Thus, the accumulation probably developed in a shoreface setting that gave rise to some aeolian dunes at the top.

All the sandy materials deposited during the Permian were characterised by extreme dryness. Thus, the assumption that the rise and fall in sea-level was directly controlled by climatic variations can be ruled out. By contrast, the regionally 


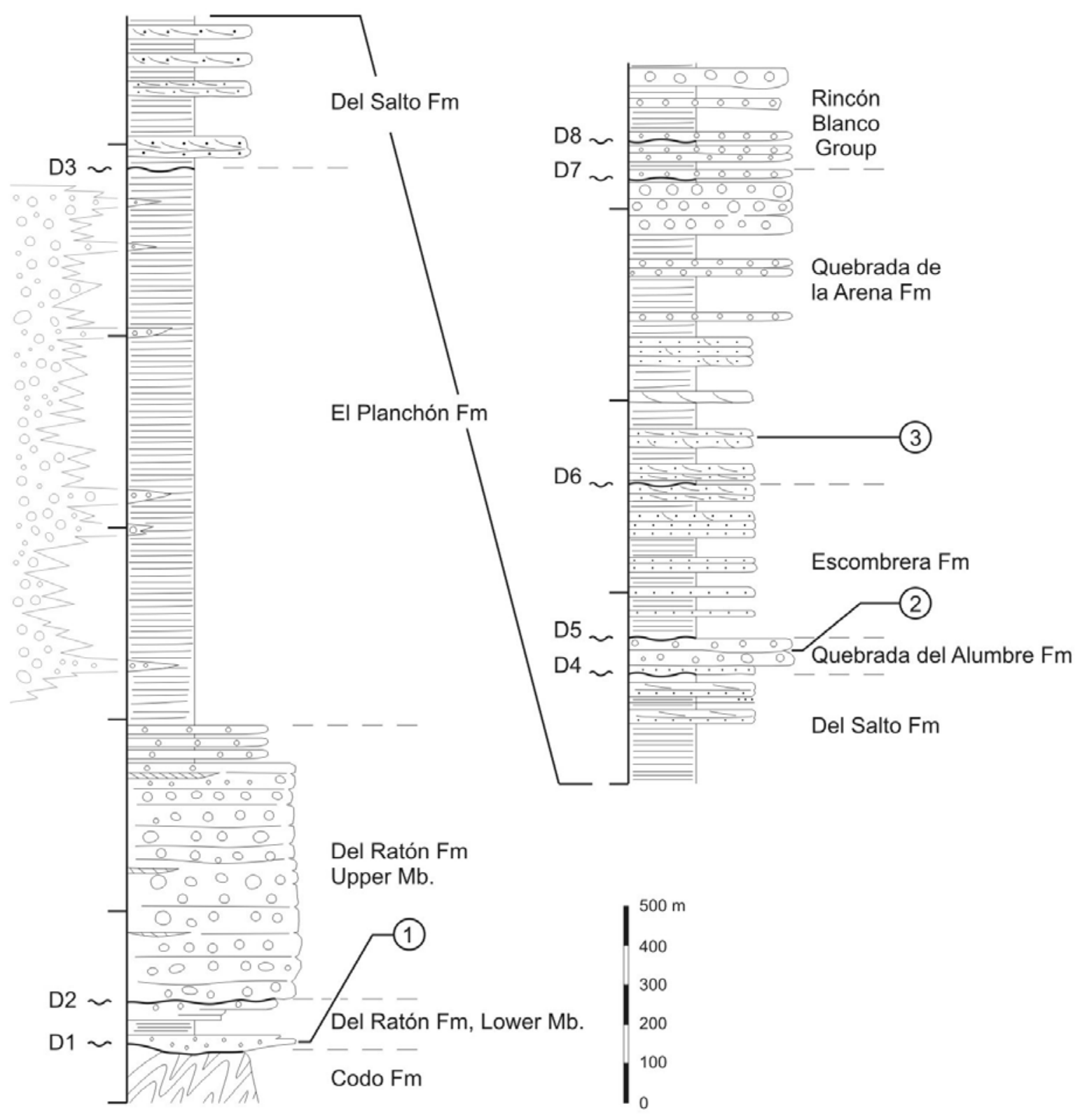

Fig. 14.- Synthetic stratigraphic log of the main lithostratigraphic units. Sample sites $(1,2,3)$ for absolute dating.

significant base-level oscillations controlled by extensional tectonic activity could be possible. This activity played a major role in the Triassic (Barredo and Stipanicic, 2002) with minor activity in the area during the middle Permian.

\subsection{Quebrada de la Arena Formation (new unit)}

This reddish Formation is made up of shales, sandstones and conglomerates. Two members may be distinguished as a result of the variable amount of these materials. The new denomination is derived from neighbouring Quebrada de la Arena located in the area where the unit crops out (Fig. 16).

Lower Member: This unit, which is about $180-200 \mathrm{~m}$ thick and comprises intercalated beds of sandstones and mudstones, overlies the Escombrera Formation with a smooth un- conformity (D6). The member is made up of more than four sandstone-dominated megasequences separated by intercalated levels of mudstones. The thick sandstone levels usually show different types of cross-bedding such as megarriples, hydraulic dunes, bars and other minor structures. The central part of each megasequence is characterised by metric trough cross-bedding which laterally show significant changes in size. Associated with the main thick sandstone levels are climbing ripple-type cross laminations locally. Many small intercalacions of mudrocks are displayed towards the summit of the unit. A thin cineritc level (Fig. 14, site 3), intercalated in the basal levels of the unit gives information of an absolute chronology between $238 \pm 1.5 \mathrm{Ma}$ and $240 \pm 3.5 \mathrm{Ma}$. Thus, the unit accumulated during the middle Triassic near the limit between the Anisian and Ladinian. 

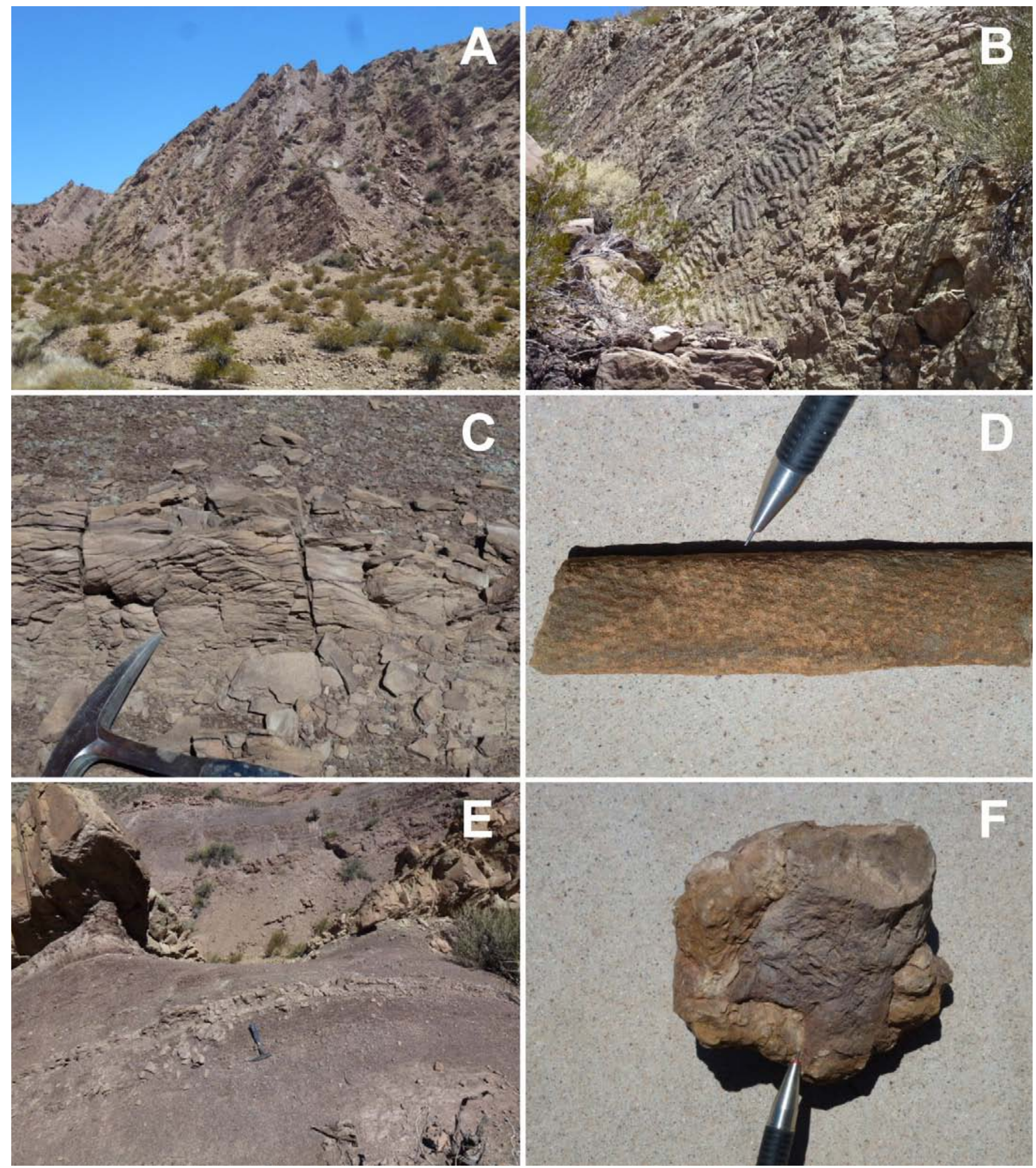

Fig. 15.- Escombrera Formation. A) Upper sequence disposition; B) large scale ripples at the summit of some sandy sequences; C) Climbing ripple cross-lamination. Quebrada de la Arena Formation. D) Lycopsidae trunk cast; E) Sequences cropping out in the upper part of the unit; F) Root cast. Pencil tip as scale. Upper part of the unit.

Interpretation: The vertical and lateral arrangement of the small units together with the distribution of sedimentary primary structures and the variety of through cross-bedding sug- gests that the unit was deposited by sand-dominated braided rivers. The mudstone-dominated major intercalations seem to have been produced by the occasional abandonment of 


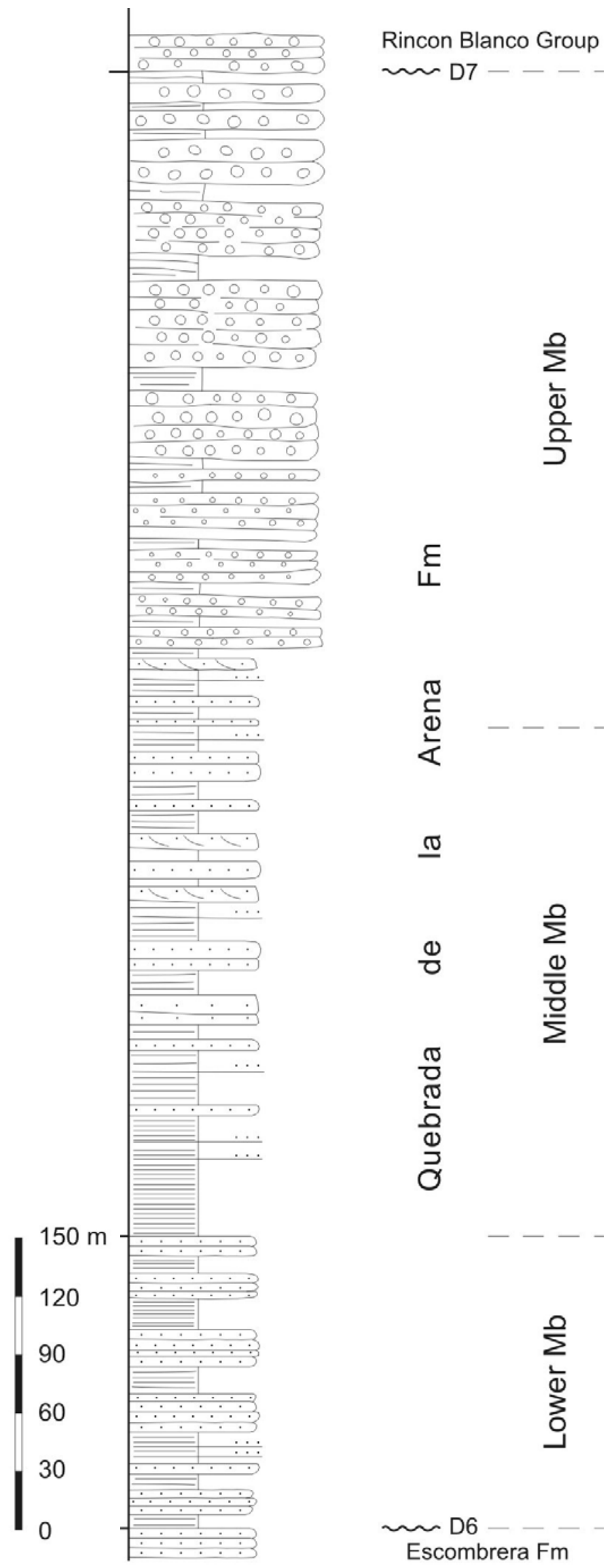

Fig. 16.- Synthetic stratigraphic log of the Quebrada de la Arena Formation. Three members can be distinguished. the sedimentary activity of the environment. The whole unit graded into a shallowing upwards depositional environment that gave rise to some ponded areas or small lagoons. Several rooting systems and Lycopsidae stems have been found in one of the fine-grained sections interpreted as coastal lagoons. They are presented as mould-cast forms and the dispersed foliage was not found in the same beds. The stems of the Lycopsidae seem to have had small diameters (c.a. 30 $\mathrm{mm}$ ), retaining (without much detail) the characteristic external rhombic leaf cushions. The associated rhizomes have larger diameters, reaching $60 \mathrm{~mm}$. Lycopsidae were typical of wetland vegetation during the late Paleozoic-Triassic. The evidence therefore suggests that the fossil beds resulted from short flooding events of the muddy-dominated areas where the Lycopsidae flourished before the inflow of the clastics in which the stems were buried. A rapid change from wetness to dry conditions is assumed.

Middle Member: This unit, which is about $220-250 \mathrm{~m}$ thick, is made up of sandstones intercalated with mudstones. Muddy materials with few intercalations of sandstones are present in the lower part. Some sandstone levels grade into conglomerates towards the top in the middle part. This unit shows different types of cross-stratification magnified by clast alignments locally. The sections are metric and incorporate abundant mud clasts locally. The basal surface of some sandstone levels displays mud crack casts (Fig. 12C). The sandstones show a planar stratification that is locally crude. Medium-scale trough cross-stratifications are present towards the middle part. The upper section displays some large diagonal structures and lineations. The shales are interfingered with thin sandstone levels with different types of cross-lamination. They are mainly composed of clays and siliceous silts and display variable amounts of water-reworked ash deposits.

Interpretation: Some waterways initially carried large amounts of muddy materials deposited in a playa-lake setting (continental mudflats). Thereafter, the sedimentary context underwent some changes, enabling the confined courses to carry large amounts of sandy-dominated bed-load materials towards the playa-lake. Following the loss of confinement of these channels, the area was affected by several events of water discharge. A number of high-energy episodes are evidenced by sedimentary structures such as parting lineations and large-scale and low-angle cross bedding. Planar crossstratifications suggest that some sandstone levels were deposited by sheet flood episodes locally. Subsequently, the main channels graded into meandering courses as evidenced by some diagonally-dominated large-scale cross bedding probably because of lateral accretion in point bars. The interfingered heterolitic levels could be due to several crevasse-splay episodes (Fig. 12D).

Upper Member: This unit, which is composed of conglomerates and sandstones, varies from 300 to $350 \mathrm{~m}$ in thickness. The conglomerates display several medium-scale and highangle cross-stratifications, some of which show concave-up 
SE-NW

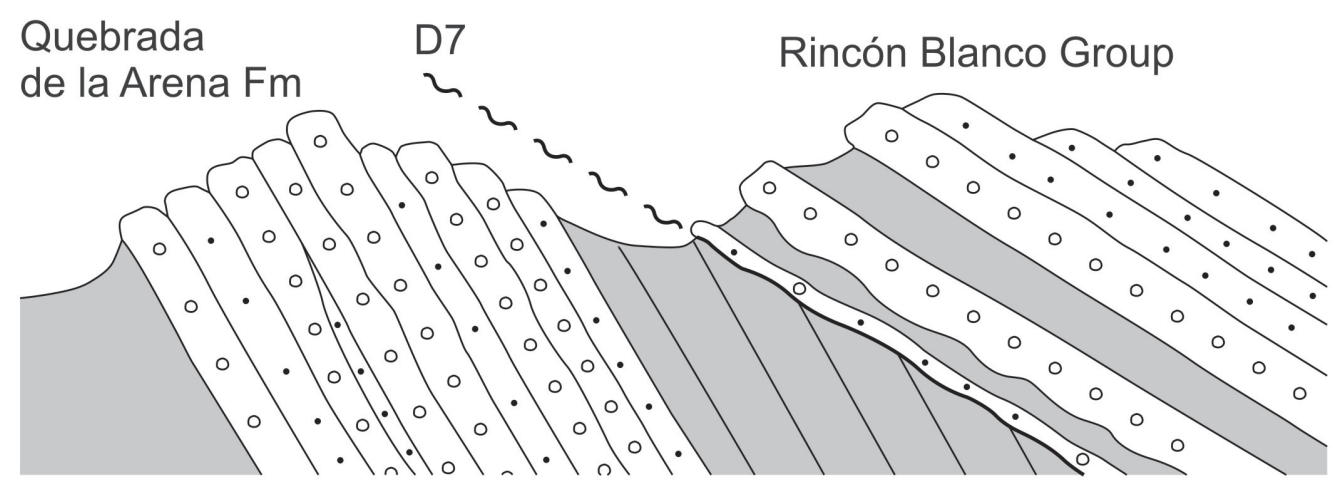

Fig. 17.- Angular unconformity over the upper section of the Quebrada de la Arena Formation. scars in the lower part. The main cross-bedding is evidenced by clast lineations. The clasts are made up of graywackes, sandstones and well rounded pink quartz. Some of them are from former reworked conglomerates. Poorly-sorted sandy shales intercalated with conglomerates are present. The upper part of the unit is characterised by coarse-grained levels which display massive-dominated facies evidenced by the predominance of matrix-supported conglomerates (Fig. 15).

Interpretation: The medium-scale cross bedding suggests that the coarse-grained materials in the lower part were transported by hydraulic flows in a braided environment where the gravel load gradually increased upwards. Subsequently, when the mass flow-dominated levels became predominant, the accumulation was produced by a number of debris flow episodes. The main coarsening and thickening upwards sequence indicates that the gradual progradation of an alluvial system was caused by erosional processes related to the new extensional ranges (Figs. 17, 18) to the east of the study area.

A marked angular unconformity (D7) separates this stratigraphic unit from the overlying Rincón Blanco Group (López-Gamundí 1994). However, in the vicinity of the study area the Upper Permian (Choiyoi Group and equivalents) is clearly extensional and unconformably covers the Gondwanan structures (Heredia et al., 2012). The last angular unconformity (D8) probably developed within the Rincón Blanco Group as a result of an extensional tectonic reactivation coeval with the Triassic sedimentary accumulation.

\section{Sedimentary evolution}

During the early Carboniferous (late Tournasian-Visean), a small fjord developed on a sharp angular unconformity

\section{W-E}

Fig. 18- Angular unconformity in the basal section of the Triassic Rincón Blanco Group ("sensu lato").

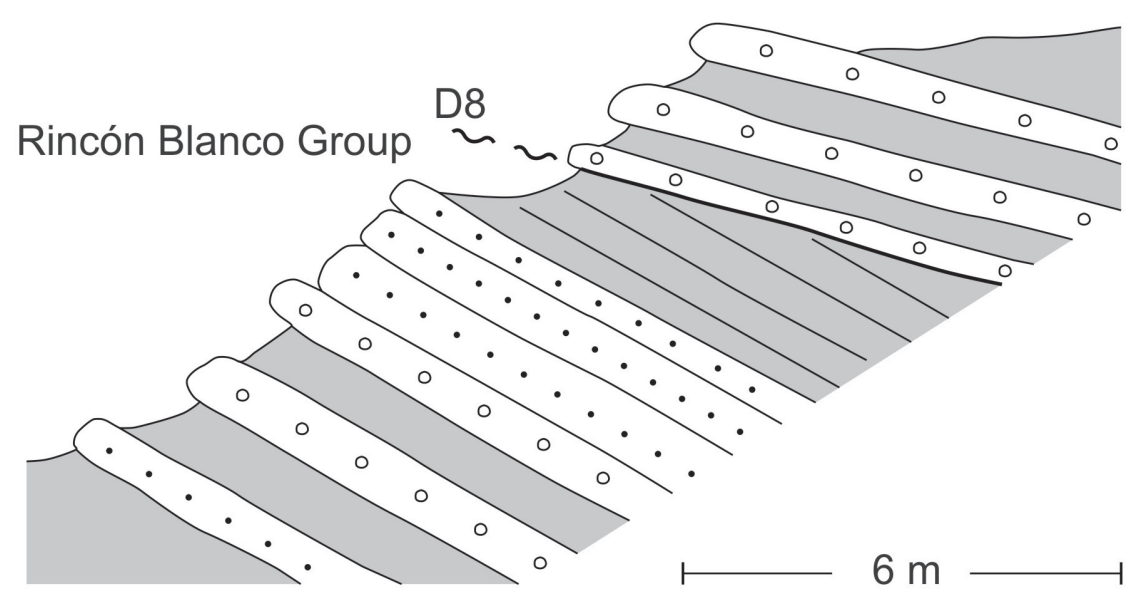



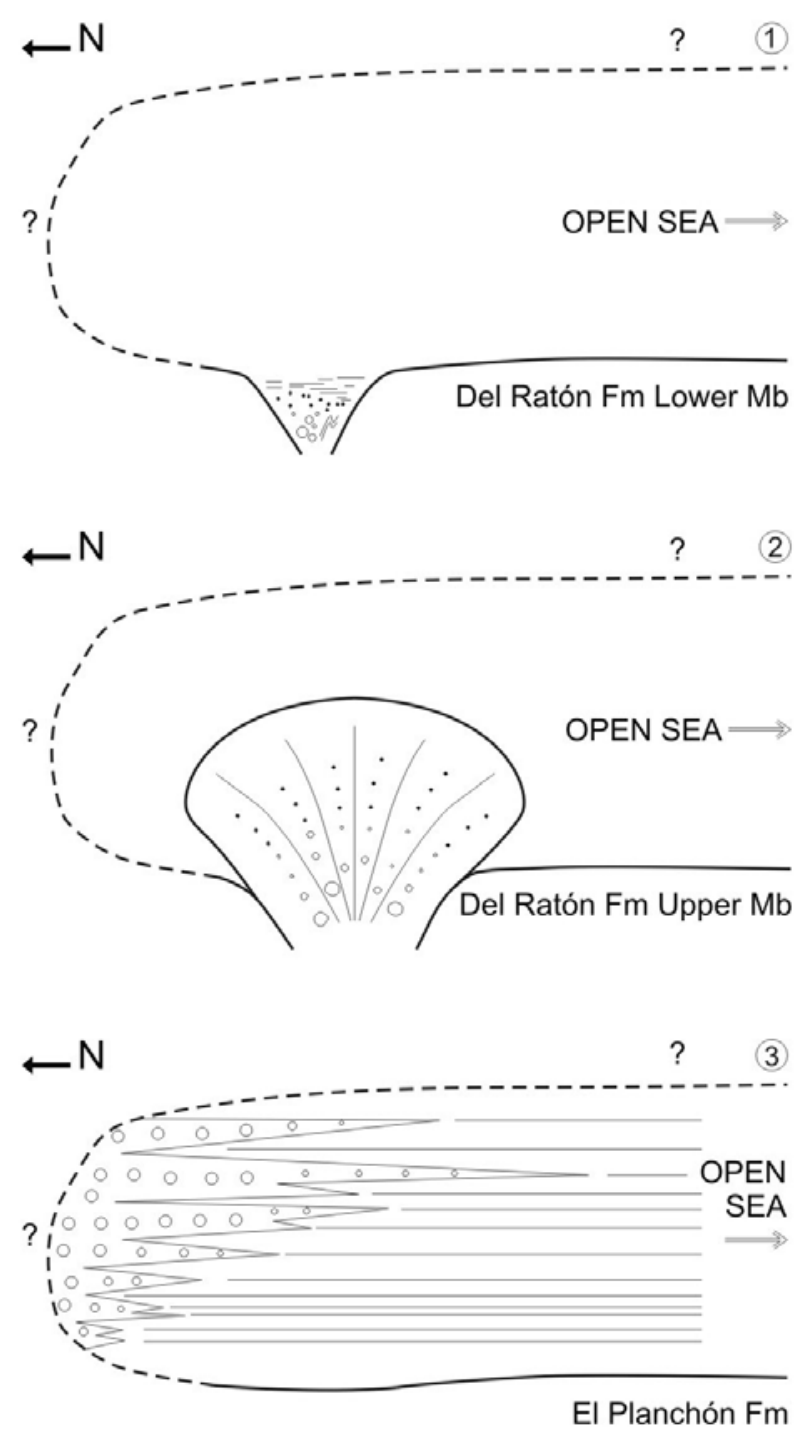

Fig. 19.- Evolution of the sedimentary infill. 1) The basal materials of the Del Ratón Formation Lower Member accumulated in a Fjord setting; 2) The main alluvial fan evolved into a fan delta. The Del Ratón Formation, Upper Member; 3) Conglomeratic tillites of the El Planchón Formation interfingered with turbidite-dominated lutitic materials.

(D1) on the Devonian basement. After its sedimentary infilling, another smooth unconformity (D2) developed before the generation of an alluvial fan system (Del Ratón Formation) which evolved into a coastal fan delta probably at the beginning of the Chanic orogeny. A marked rise in relative sealevel led to the development of the El Planchón Formation in a deep-sea fan setting. This Formation represents the end of the synorogenic Chanic sedimentation. The rapid sea level rise was probably due to an event of regional deglaciation. The Lower Carboniferous rocks were then deformed and exposed to subaerial alteration as evidenced by the rubefaction (Fig. 19) of the mudrocks located below the main angular unconformity (D3). The subaerial exposure was probably much
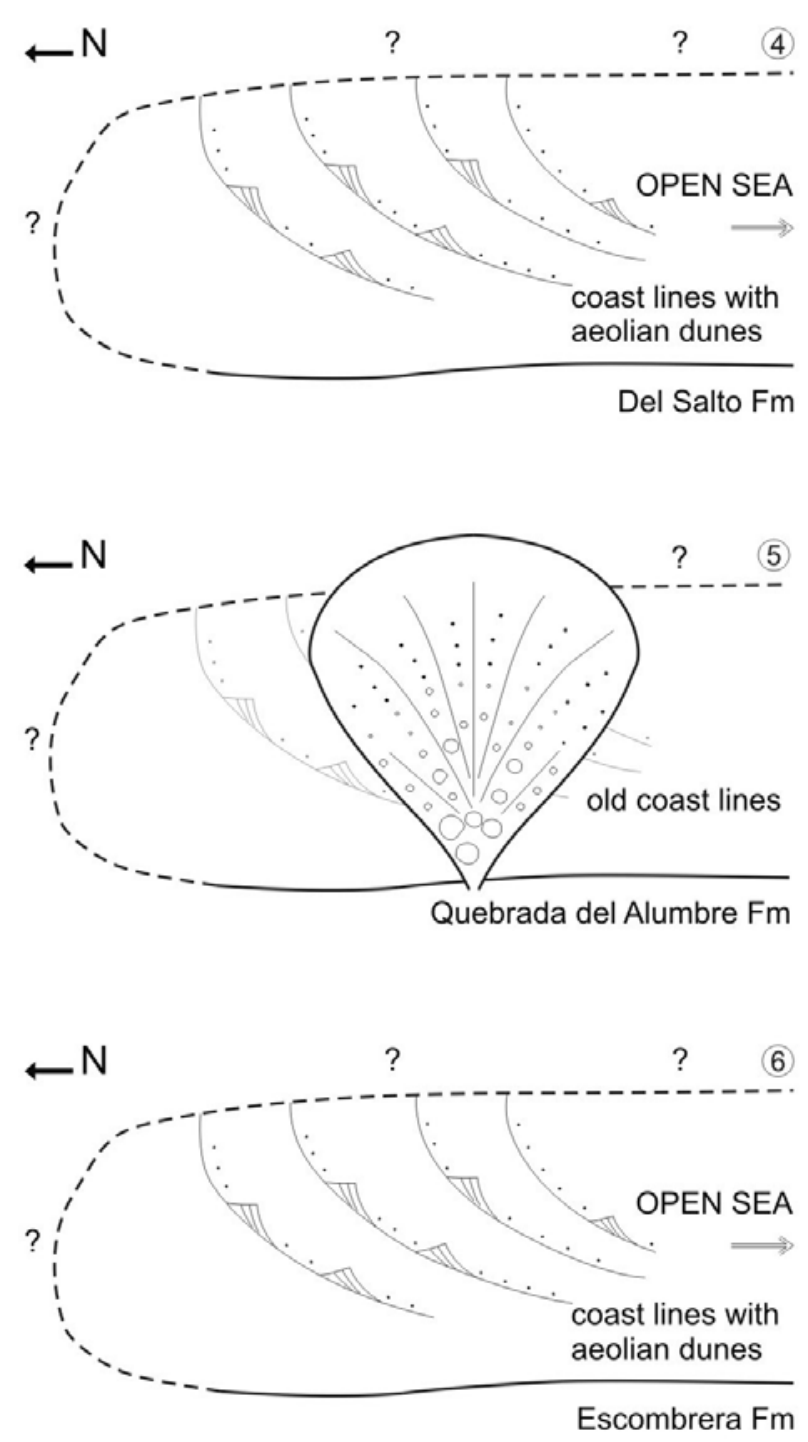

Fig. 20.- Evolution of the sedimentary infill. 4) Del Salto Formation coastal sandy accumulations; 5) Conglomeratic deposits of the Quebrada del Alumbre Formation, Alluvial fans; 6) Escombrera Formation coastal sandy accumulations.

longer since no new deposits accumulated until the Permian. Thus, during most of Carboniferous, this area was part of a basement high (horst) known as the Protoprecordillera, a remnant of the Chanic cordillera, which was located between the Río Blanco and Paganzo extensional basins (Heredia et al., 2012).

During the basal Permian, an expansive coastal system (Del Salto Formation) accumulated on a sharp angular unconformity (D3), the open-sea being located to the south. This Permian Formation developed as a sedimentary response (Fig. 3 ) to the erosion of the Gondwanan orogenic ranges and was deposited in the same retroarc foreland basin located in the Frontal Cordillera at this latitude (Busquets et al., 2005). The 

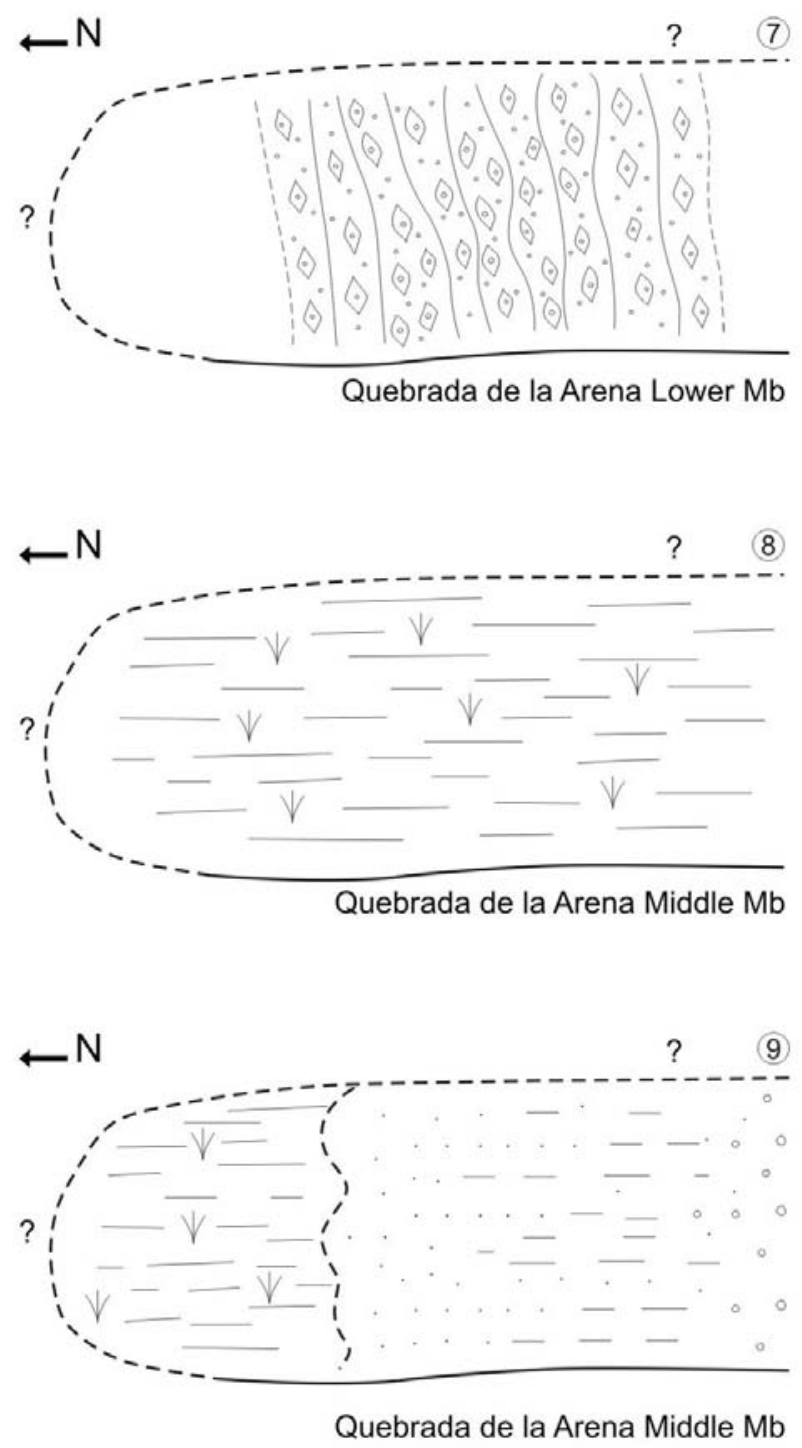

Fig. 21.- Evolution of sedimentary infill. 7) Quebrada de la Arena Formation, Lower Member. Sand-dominated braided watershed; 8) Muddominated Playa-lake; 9) Sheet flows and ephemeral streams

Protoprecordillera disappeared at the start of the Permian owing to the flexural subsidence associated with the origin of the Gondwanan foreland basin (Heredia et al., 2012).

The Andean cycle, which was characterised by an extensional tectonic setting, started in the middle Permian. In this context, a transverse alluvial fan system (Quebrada del Alumbre Formation) was deposited over another unconformity (D4). These coarse-grained rocks were transported from new ranges located to the west (Fig. 20). Subsequently, a new expansive coastal system (Escombrera Formation) was deposited over a smooth unconformity (D5). This unit seems to be the last Palaeozoic sedimentary accumulation.

A sand-dominated (Fig. 21) braided watershed (Quebrada de la Arena Formation) accumulated on a smooth uncon-
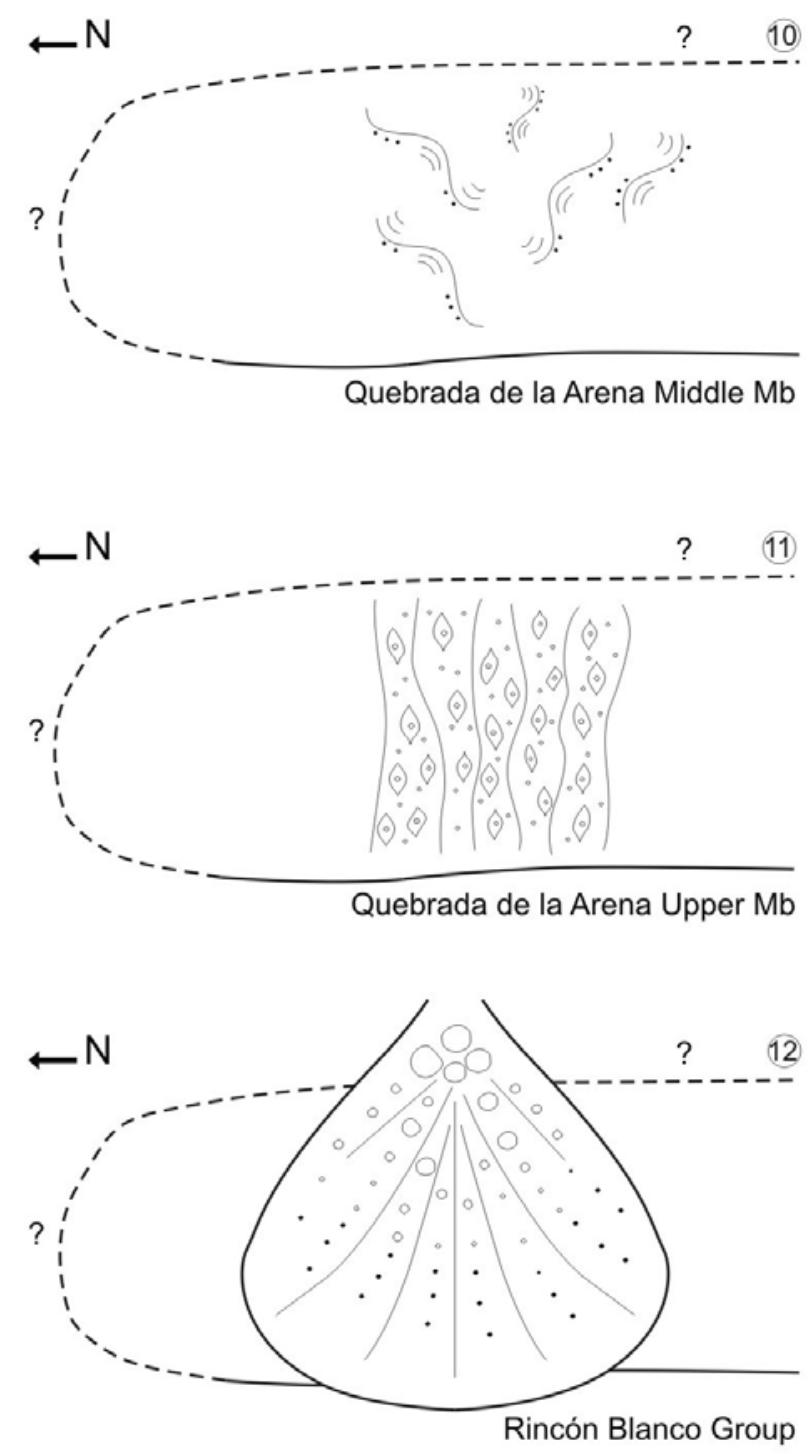

Fig. 22.- Quebrada de la Arena Formation sedimentary infill evolution. 10) Middle Member. Meander belts; 11), Upper Member. Braided rivers; 12) Upper Member. Alluvial fans.

formity (D6) and gradually evolved into a mud-dominated playa lake. Subsequently, a sheet-flood dominated sand accumulation (Lower Member), which was replaced (Fig. 22) by a meandering system (Middle Member), developed. Thereafter, this system progressively changed to another braided sedimentary environment overlain by conglomeratic and progradational alluvial fans from the east (Upper member).This unit was the first Triassic accumulation in the study area.

The Rincón Blanco Group ("sensu lato") accumulated over an angular unconformity (D7). It displays another angular unconformity locally (D8) that was generated by the reactivation of the Andean extensional activity during the Triassic (Stipanicic, 1972, 2002; Ramos et al., 1986; Spalletti, 1999; Ramos, 2004; Mancuso et al., 2010). 


\section{Acknowledgements}

The authors are indebted to V. Ramos, T. Lawton and S.N. Césari whose comments have considerably improved the earlier versions of the manuscript. This study was funded by the Spanish Proyecto de Investigación CGL2009-13706-C03-03 BTE of MINCINN and by the Grup de Qualitat, 2009-SGR1198. Secretaria de Universitats i Recerca. Departament d'Economia i Coneixement. Generalitat de Catalunya.

\section{References}

Alonso, J. L., Rodríguez-Fernández, L. R., García-Sansegundo, J., Heredia, N., Farias, P., Gallastegui, J. (2005a): Gondwanic and Andean structure in the Argentine central Precordillera: The Río San Juan section revisited. VI International Symposium on Andean Geodynamics (ISAG 2005), Barcelona, Extended Abstracts: 36-39.

Alonso, J. L., Farias, P., Rodríguez-Fernández, L. R., Heredia, N., García-Sansegundo, J. (2005b): Stratigraphic location of the Planchón Conglomerates (Western Argentina Precordillera, San Juan River). Gondwana 12, Academia Nacional de Ciencias, Córdoba. Abstracts, p. 41. Mendoza.

Alonso, J.L., Gallastegui, G., García-Sansegundo, J., Farias, P., Rodríguez-Fernández, L.R., Ramos, V.A. (2008): Extensional tectonics and gravitational collapse in an Ordovician passive margin: The Western Argentina Cordillera. Gondwana Research 13, 204-215. doi: 10.1016/j.gr.2007.05.014

Amenábar, C.R., di Pasquo, M. (2008): Nuevos aportes a la palinología, cronología y paleoambiente de la Precordillera Occidental de Argentina: formaciones El Planchón, Codo (Devónico) y El Ratón (Mississippiano). Acta Geológica Lilloana 21 (1), 3-20.

Archangelsky, S. (ed.), (1987): El Sistema Carbonifero en la República Argentina. Academia Nacional de Ciencias de Córdoba, 412pp. Córdoba.

Archangelsky, S. (ed.), (1996): El sistema Pérmico en la República Argentina y en la República Oriental del Uruguay. Academia Nacional de Ciencias de Córdoba, 584pp. Córdoba.

Astini, R., Ramos, V.A., Benedetto, J.L., Vaccari, N.E. (1996): La Precordillera: un terreno exótico a Gondwana. XIII Congreso Geológico Argentino y III Congreso Exploratorio de Hidrocarburos, Actas V, 293-324.

Azcuy C.L., Césari, S.N., Longobucco, M. (1981): Las plantas fósiles de la Formación El Ratón (Provincia de San Juan). Ameghiniana 18 (1-2), 11-28.

Barredo, S., Chemale, F., Marsicano, C., Àvila, J.N., Ottone, E.G., Ramos, V.A. (2012): Tectono-sequence stratigraphy and U-Pb zircon ages of the Rincón Blanco Depocenter, northern Cuyo Rift, Argentina. Gondwana Research, 21, 624-636. doi:10.1016/j.gr.2011.05.016

Barredo, S., Stipanicic, P. (2002): El Grupo Rincón Blanco. In: P. Stipanicic, C. Marsicano, (eds.), Léxico Estratigráfico de la Argentina. Asociación Geológica Argentina Serie B, Didáctica y Complementaria $26,113-114$.

Boulton, G.S., Dobbie, K.E., Zatsepin, S. (2001): Sediment deformation beneath glaciers and its coupling to the subglacial hydraulic system. Quaternary International 86, 3-28. doi:10.1016/S10406182(01)00048-9

Colombo, F., Limarino, C.O., Spalletti, L.A., Cardó, R., Busquets, P., Méndez Bedia, I., Heredia, N. (2012): Unidades neopaleozoicas en la Precordillera de San Juan, Argentina. Características sedimentarias de las Formaciones Del Ratón, El Planchón y Del Salto. Geo-Temas, 13, 558.

De Rosa, L.A. (1983): Sedimentitas continentales del Carbónico inferior en el flanco occidental de la precordillera. Dpto. Calingasta, Provincia de San Juan._Asociación Argentina de Mineralogía, Petrología y Sedimentologia 14 (3-4), 51-69.

Etchichury, M.E., Tófalo, O.R., Forzinetti, M.E. (1990): Depósitos de flujos efímeros en la Formación Del Salto (Paleozoico Superior, Provincia de San Juan). III Reunión Argentina de Sedimentología Actas I: $295-300$

Evans, D.J.A. (2003): Ice-Marginal terrestrial landsystems: Active temperate glacier margins. In: D.J.A Evans,.(ed.), Glacial Landsystems Chap. 2, 12-43. Arnold Publ., London. doi: 10.1002/esp.1224

Gradstein, F.M, Ogg, J.G., Schmmitz, M.D. et al., (2012): The Geologic Time Scale. Boston, USA, Elsevier. doi: 10.1016/B978-0-444-594259.00004-4. Consulted, 12-05-2012.

Guerstein, M.B., Laya, H.A., Pezzutti, N.E. (1965): Bosquejo fotogeológico de la zona "Las Juntas" (Dpto. Calingasta, Provincia de San Juan). Actas Segundas Jornadas Geológicas Argentinas. Tomo 3. Acta Geológica Lilloana VII, 231-242. Tucumán.

Heim, A. (1952): Estudios tectónicos en la Precordillera de San Juan. Los ríos de San Juan, Jáchal y Huaco. Asociación Geológica Argentina, Revista 7 (1), 11-70.

Heredia, N., Farias, P., García-Sansegundo, J., Giambiagi, L. (2012): The Basement of the Andean Frontal Cordillera in the Cordón del Plata (Mendoza, Argentina): Geodynamic Evolution. Andean Geology, 39 (2), 242-257. doi: 10.5027/andgeoV39n2-a03

Iverson, N.R., Iverson, R.M. (2001): Distributed shear of subglacial till due to Coulomb slip. Journal of Glaciology, 47, 481-488.

Kerlleñevich, S.C. (1967): Hallazgo del Devónico marino en la zona de Calingasta, provincia de San Juan. Asociación Geológica Argentina, Rev. 22, 291-294.

Kerlleñevich, S.C. (1969): La edad de los “conglomerados morados" supuestamente pérmicos de la Quebrada nueva, Precordillera San Juan. Asociación Geológica Argentina, Revista 24 (3), 269-275.

Limarino, C.O., Césari, S.N. (1992): Reubicación estratigráfica de la Formación Cortaderas y definición del Grupo Angualasto (Carbonífero inferior). Asociación Geológica Argentina, Rev. 47, 61-72.

Limarino, C.O., Colombo, F., Busquets, P., Spalletti, L.A., MéndezBedia, I., Cardo, R. (2012): Aportes estratigráficos al conocimiento de la estructuración preandina entre los $29^{\circ}$ y $32^{\circ}$ de latitud sur, oeste argentino. Geo-Temas, 13, 1891-1894.

López Gamundí, O.R. (1994): Facies distribution in an asymmetric half-graben: The Northern Cuyo basin (Triassic), western Argentina. $14^{\text {th }}$ International Sedimentological Congress. Abstracts, 6-7. Recife, Brasil.

Manceñido, M.O. (1973): La fauna de la Formación Del Salto (Paleozoico superior de la Provincia de San Juan). Parte I. Ameghiniana 10, 153-235.

Manceñido, M.O., Sabattini, N. (1974): La fauna de la Formación Del Salto (Paleozoico superior de la Provincia de San Juan). Parte II. Gastropoda. Ameghiniana 10, 326-338.

Manceñido, M.O., González, C.R., Damborenea, S.E. (1976a): La fauna de la Formación Del Salto (Paleozoico superior de la Provincia de San Juan). Parte III. Bivalvia 1. Ameghiniana 13, 65-84.

Manceñido, M.O., González, C.R., Damborenea, S.E. (1976b): La fauna de la Formación Del Salto (Paleozoico superior de la Provincia de San Juan). Parte IV. Bivalvia 2. Ameghiniana 13, 85-106.

Mancuso, A.C., Chemale, F., Barredo, S.P., Ávila, J., Ottone, E.G., Marsicano, C. (2010): Age constraints fort he northernmost outcrops of the Triassic Cuyania Basin, Argentina. Jour. South Amer. Earth Sci. 30(2), 97-103. doi:10.1016/j.jsames.2010.03.001

Powell, R.D. (2003): Subaquatic landsystem: Fjords. In: D.J.A. Evans, (ed.), Glacial Landsystems, Chap. 13, 313-347. Arnold Publ., London.

Quartino, B.J., Zardini, A.R., Amos, A.J. (eds.), (1971): Estudio y explicación geológica de la Región Barreal-Calingasta, Provincia de 
San Juan, República Argentina. Asociación Geológica Argentina, Monografia 1, 184pp.

Ramos, V. A. (2004): Cuyania, an exotic block to Gondwana: review of a historical success and the present problems. Gondwana Research, 7, 1009-1026. doi:10.106/S1342-937X(05)71081-9

Ramos, V. A., Jordan, T.E., Allmendinger, R.W., Mpodozis, C., Kay, S.M., Cortés, J.M., Palma, M. (1986): Palaeozoic Terranes of the Central Argentine-Chilean Andes. Tectonics, 5, 855-880.

Sellés Martínez, J. (1985): Caracterización litoestructural de la Formación El Planchón (Devónico de la Precordillera Occidental de San Juan). Primeras Jornadas sobre Geología de Precordillera, Actas, I: 53-58.

Sessarego, H.L. (1983): La posición estratigráfica y edad del conglomerado atribuido a la Formación Del Salto. Río San Juan. Provincia de San Juan. Asociación Geológica Argentina, Rev. 38, 494-497.

Sessarego, H.L., Lech, R., Amos A.J. (1985): Estratigrafía y contenido paleontológico de la Formación Del Salto (Pérmico) aflorante al norte del río San Juan, Cerro El Brealito, Dpto. Calingasta, San Juan. Primeras Jornadas sobre Geología de Precordillera, Actas, I: 192-197.

Sessarego, H.L. (1986): Eolianitas en el Pérmico de la Cuenca Calingasta-Uspallata (Formación del Salto) Dpto. Calingasta-San Juan. $1^{a}$ Reunión Argentina de Sedimentologia. Resúmenes, 149-152.

Sessarego, H.L. (1988): Estratigrafia de las secuencias epiclásticas devónicas a triásicas aflorantes al norte del río San Juan y al oeste de las Sierras del Tigre, provincia de San Juan. PhD Thesis, Universidad de Buenos Aires, (unpublished).

Sessarego, H. L., Césari, S. N. (1989): An Early Carboniferous Flora from Argentina. Biostratigraphic implications. Review of Palaeobotany and Palynology 57, 247-264.

Spalletti, L.A. (1999): Cuencas triásicas del Oeste Argentino: origen y evolución. Acta Geologica Hispanica, 32, 29-50.

Stipanicic, P.N. (1972): Cuenca triásica de Barreal. In: A.F. Leanza, (ed.), Geología Regional Argentina, Academia Nacional de Ciencias, Córdoba, 537-566.

Stipanicic, P.N. (2002): Triásico. In: P.N. Stipanicic, C.A. Marsicano, (eds.), Léxico estratigráfico de la Argentina, Triásico. Asociación Geológica Argentina, Serie B 26, 370pp.

Taboada, A.C. (2006a): Del Salto (Formación). In: P.R. Gutiérrez, (ed.), Léxico estratigráfico de Argentina Pérmico Asociación Geológica Argentina, Serie B, 28, 107-108.

Taboada, A.C. (2006b): Tivertonia Archbold (Chonetidina, Brachiopoda) del Pérmico inferior de la subcuenca Calingasta-Uspallata, precordillera argentina. Ameghiniana 43(4), 705-716.

Venturini, R.E. (1980): Estratigrafía y estructura de la Formación El Planchón (Devónico) en la quebrada del Km 114, San Juan. Asociación Geológica Argentina, Revista 35 (4), 570-572. 